\title{
TERCERA PARTE
}

\section{DOSSIER FOTOGRÁFICO}

\author{
RETROSPECTIVAS: \\ FILIGRANAS DE UNA UNIVERSIDAD \\ PÚBLICA Y NACIONAL
}

“... lo que veo se ha encontrado allí, en ese lugar que se extiende entre el infinito y el sujeto [...] ha estado allí, y sin embargo ha sido inmediatamente separado: ha estado absoluta, irrecusablemente presente, y sin embargo diferido ya"

Roland Barthes en

La cámara lúcida: notas sobre la fotografía 



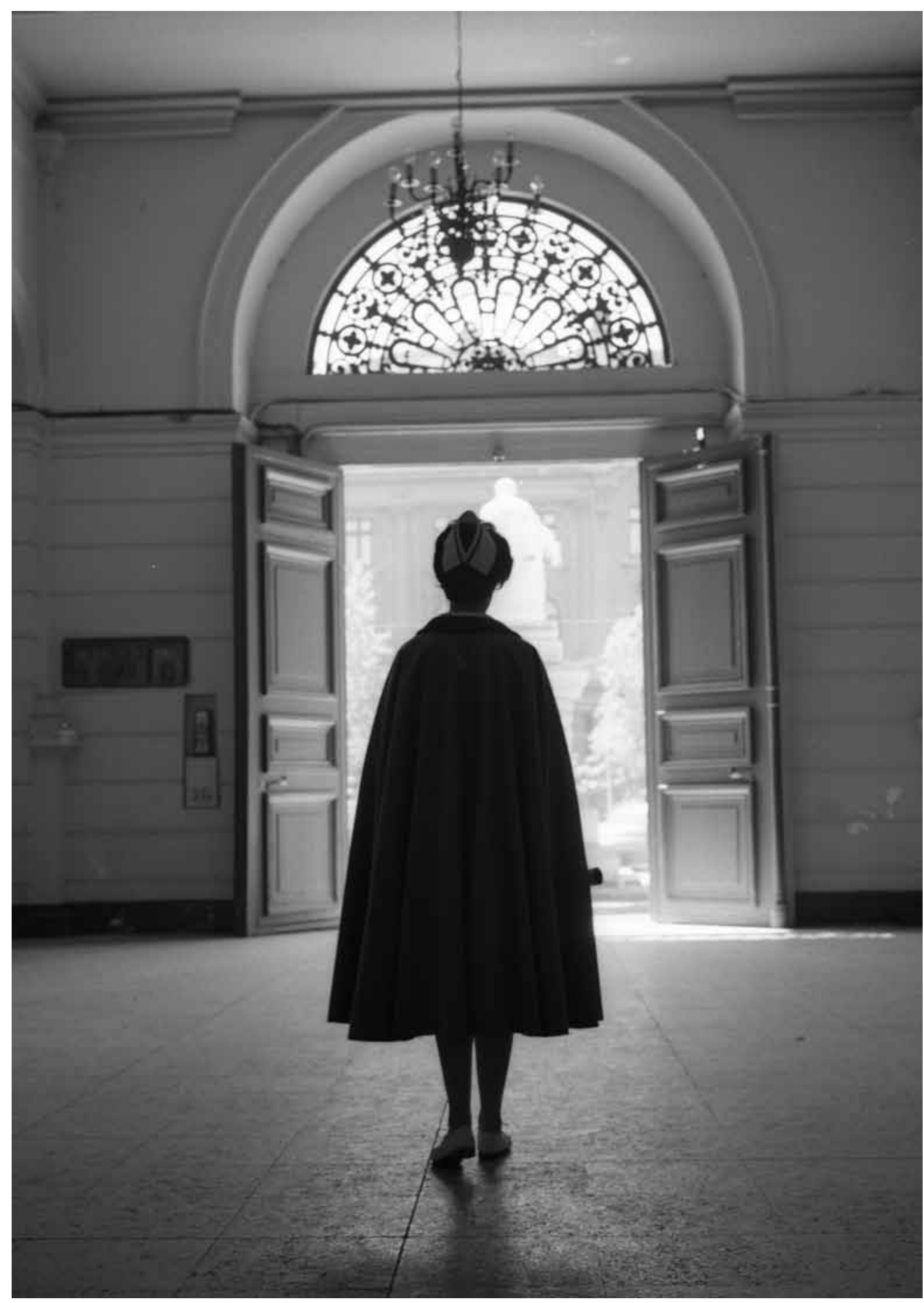




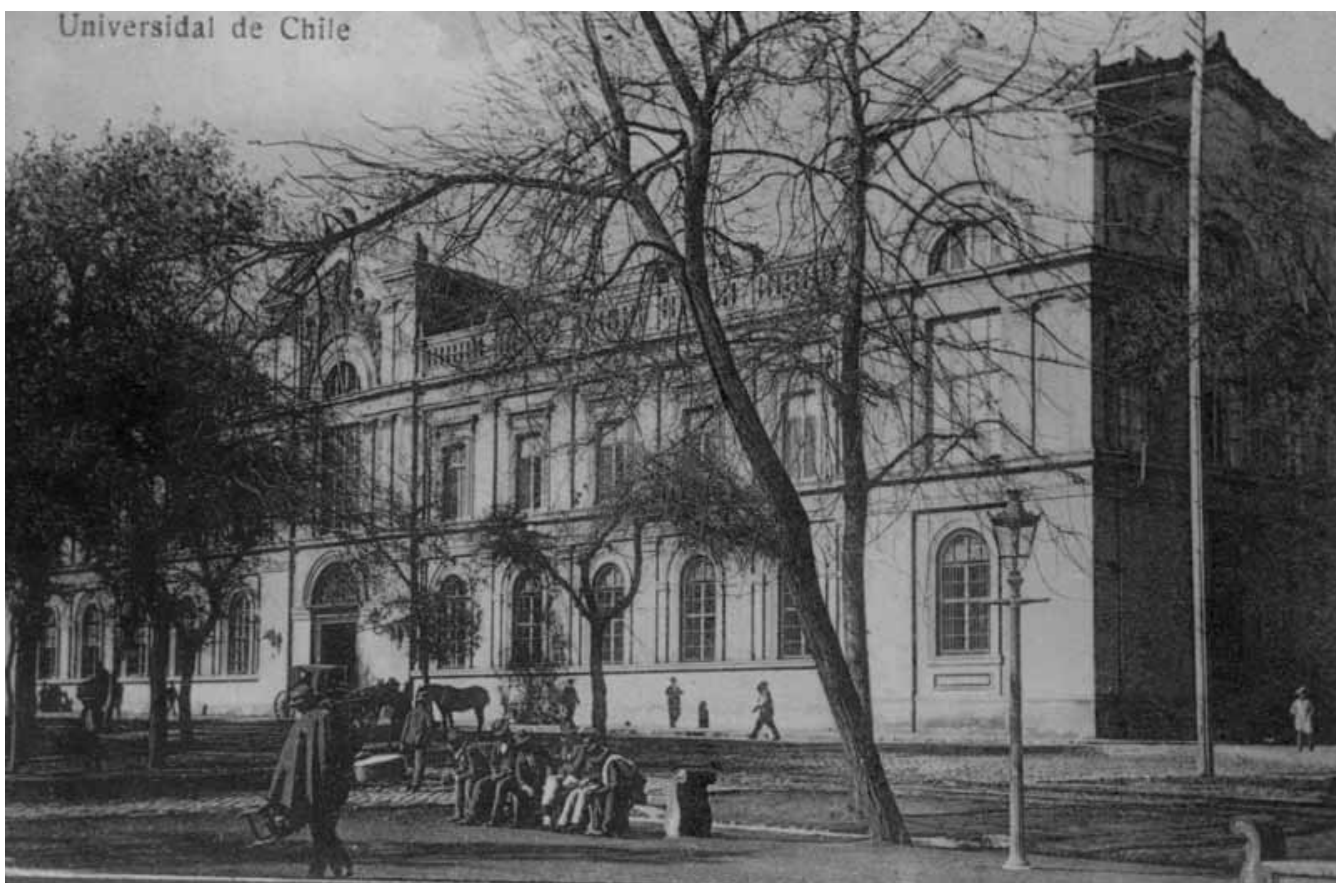

Casa Central

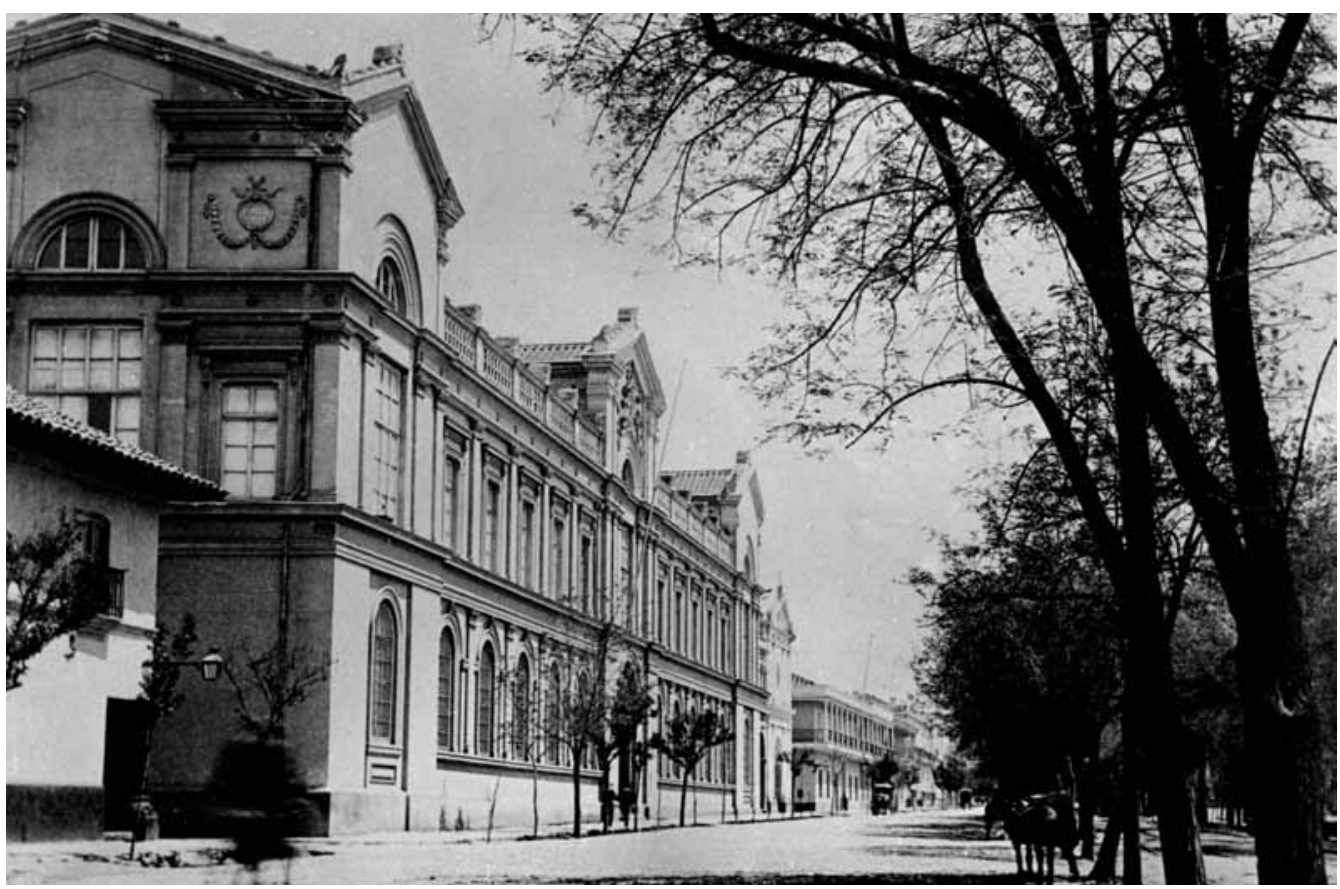

Casa Central 


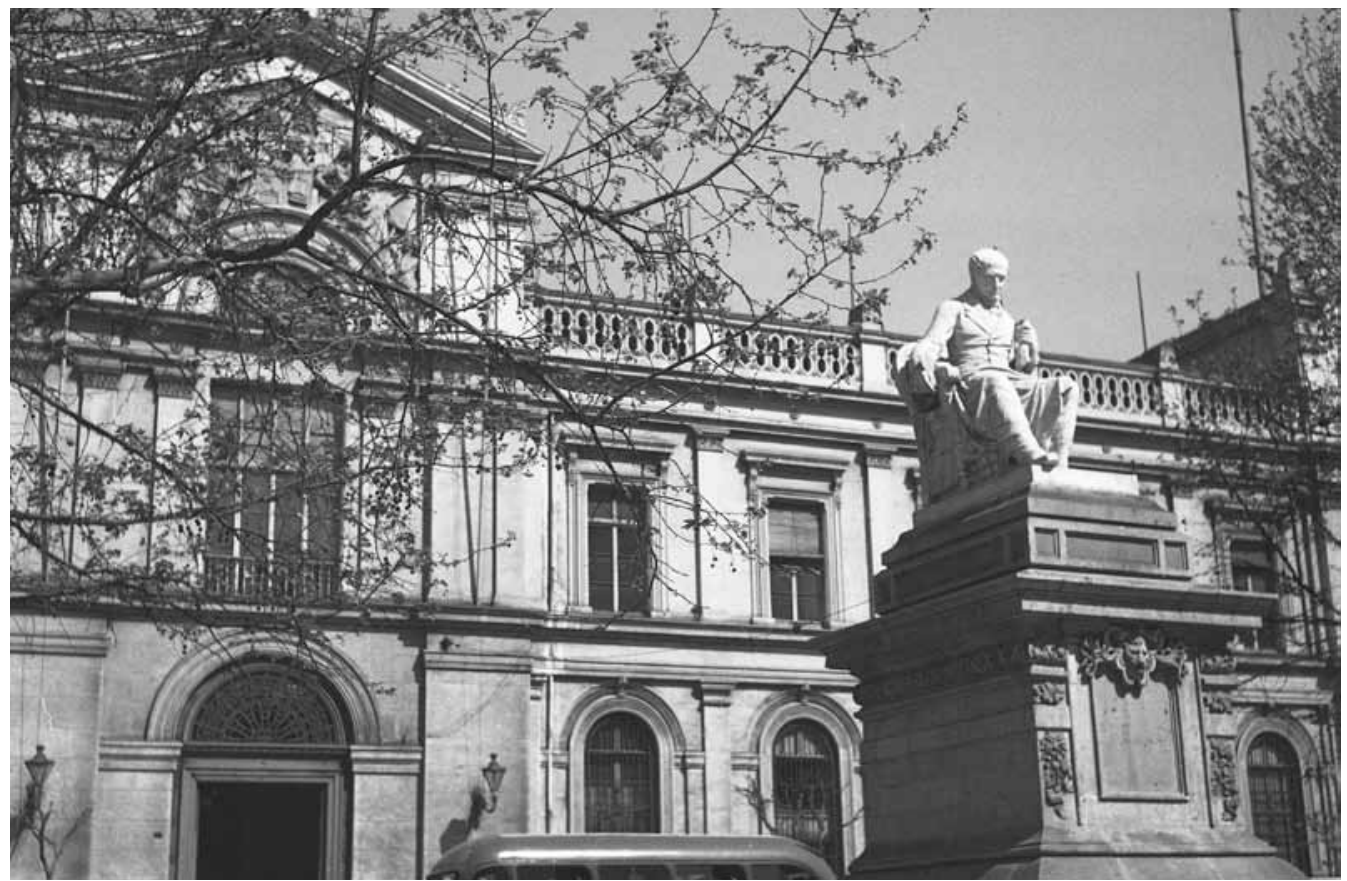

Casa Central

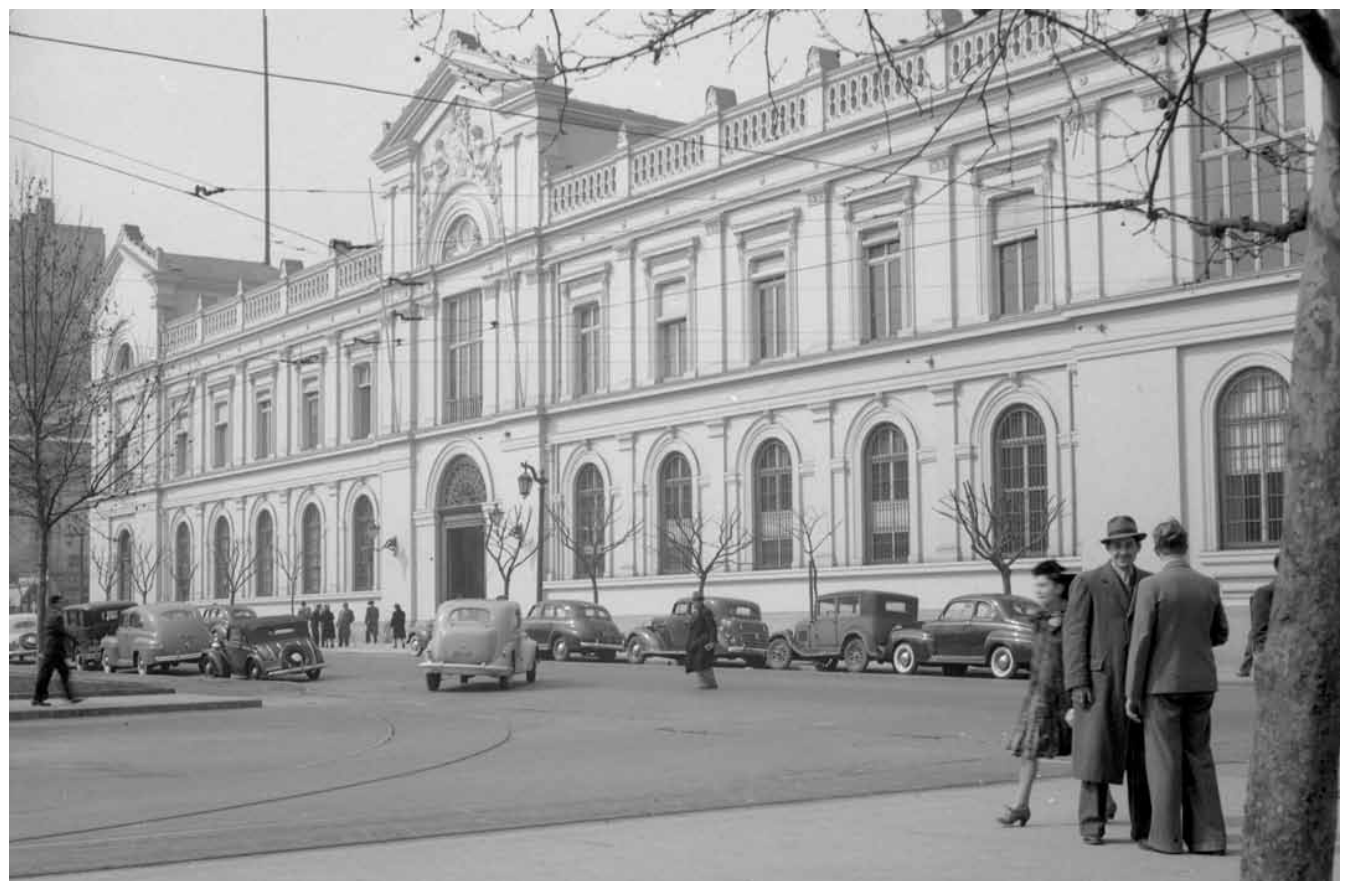

Casa Central 


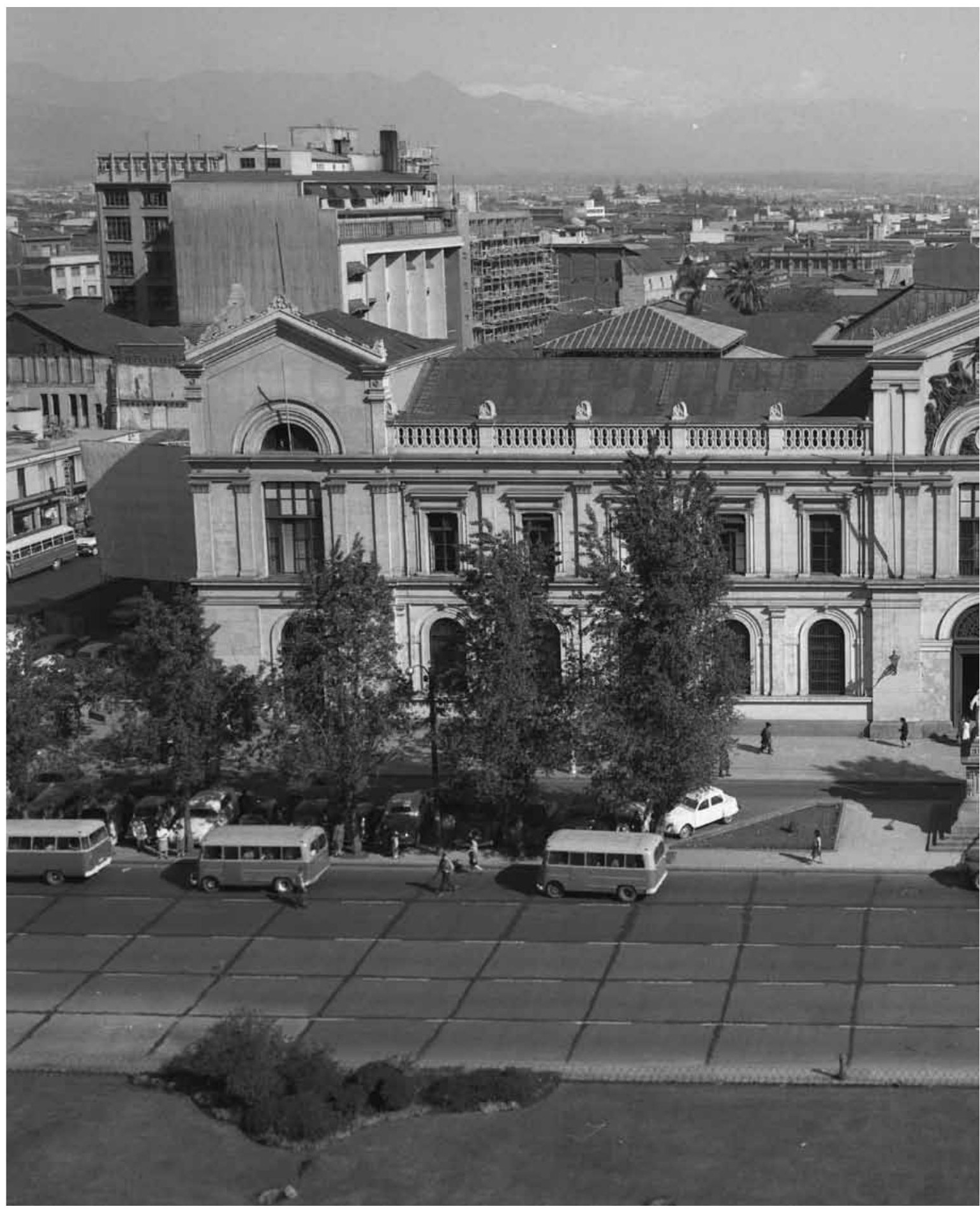




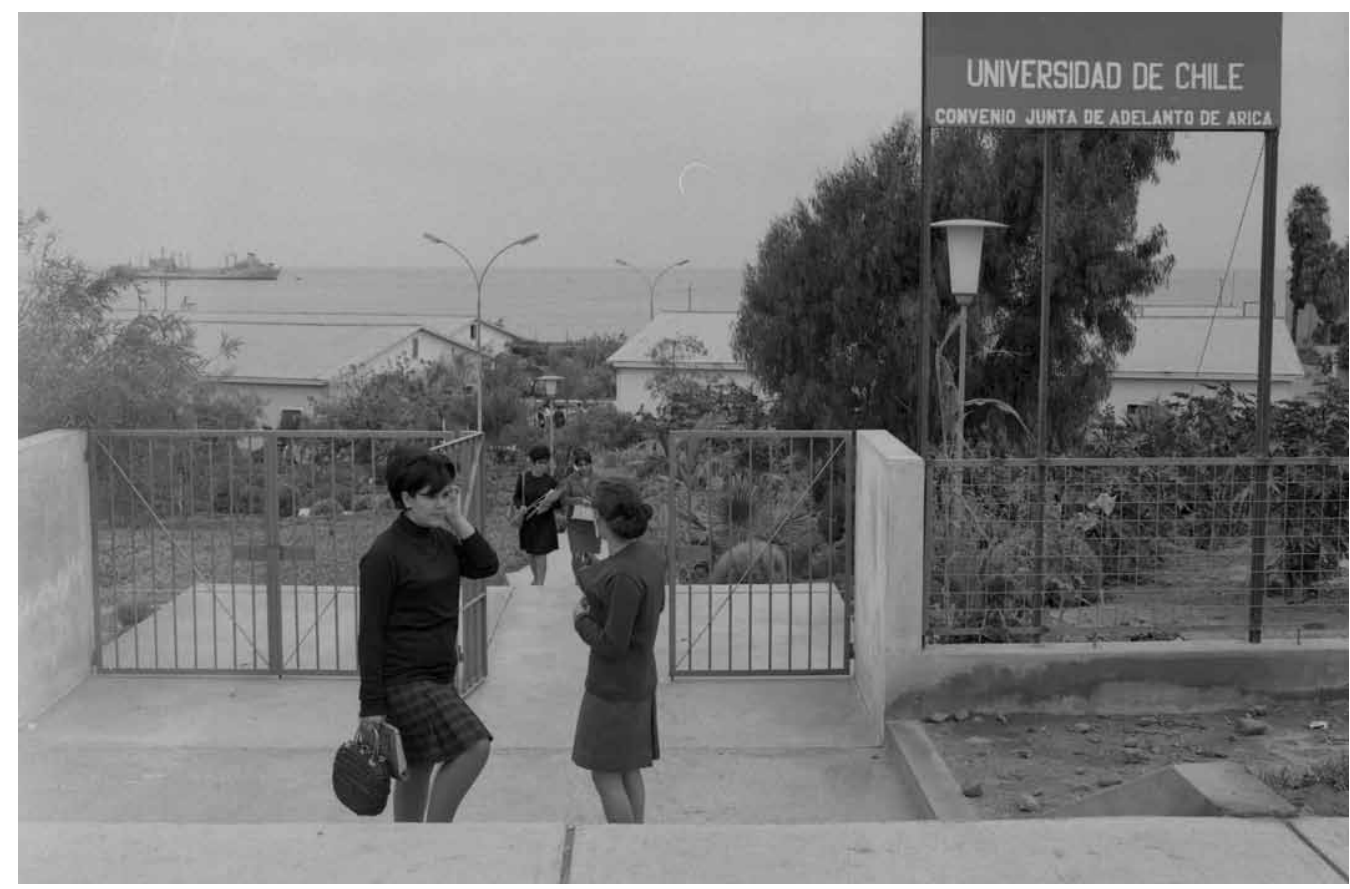

Centro universitario de Arica

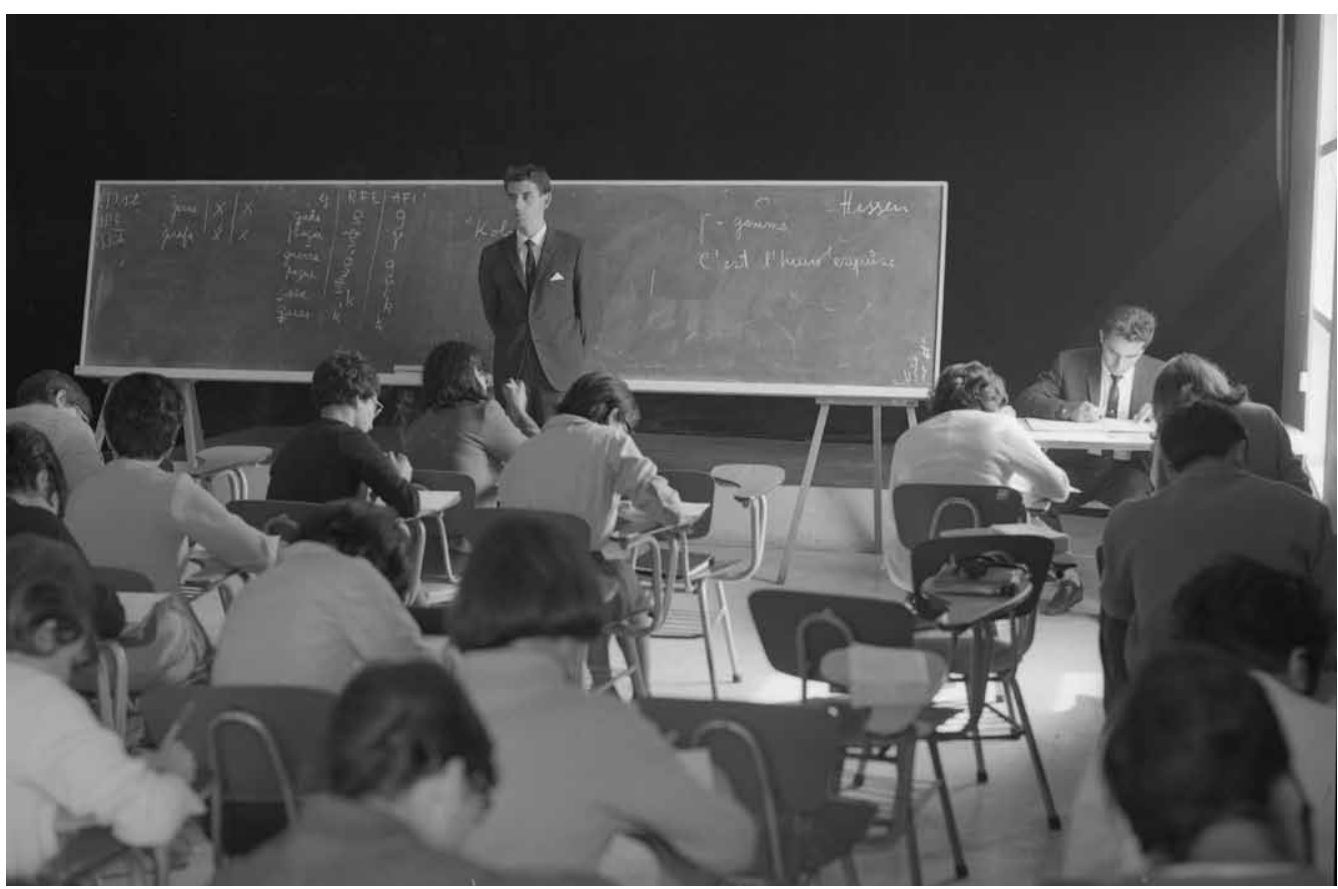

Centro universitario de Arica 


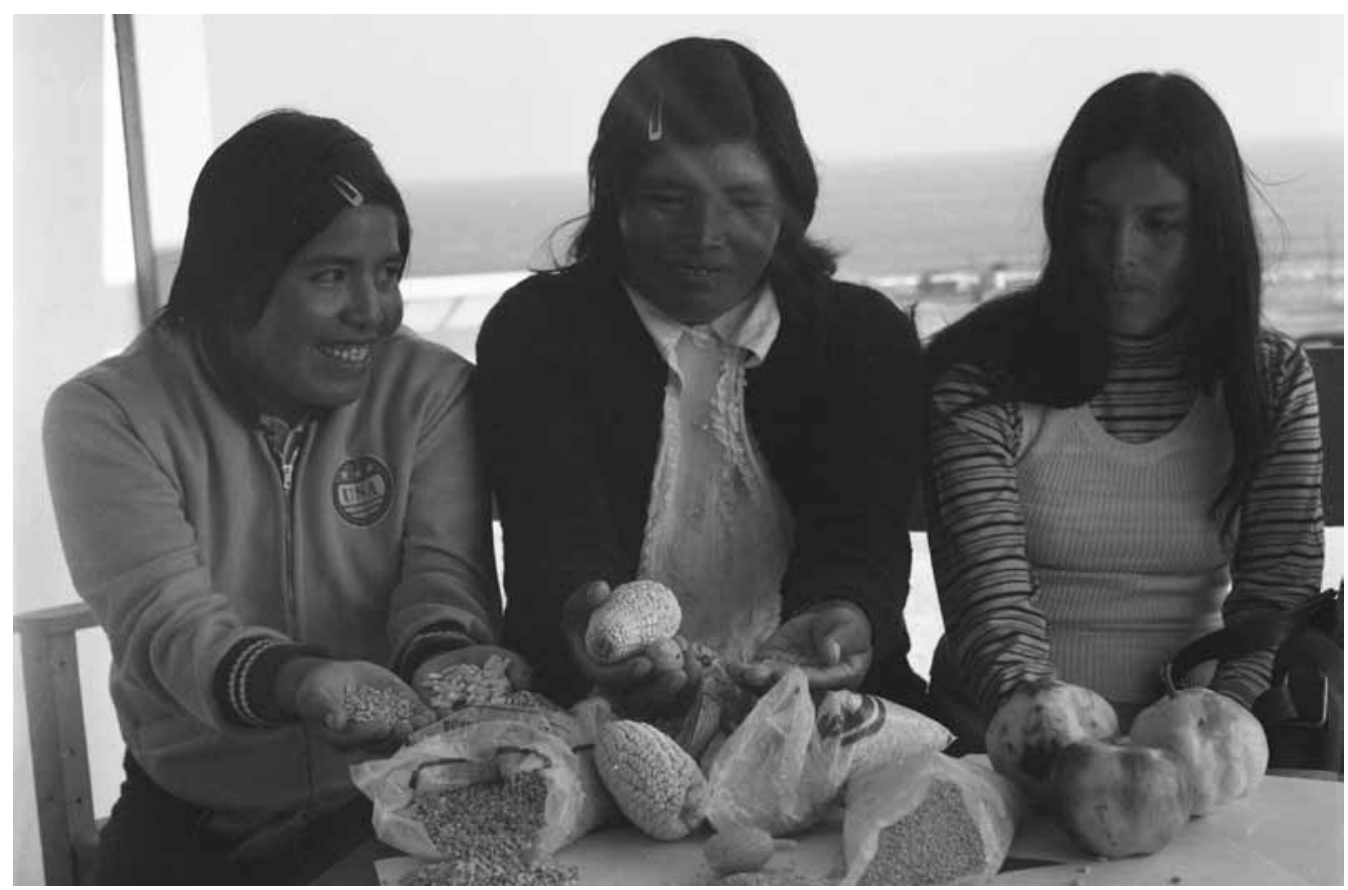

Colegio regional de Antofagasta Foto: Patricio Guzmán

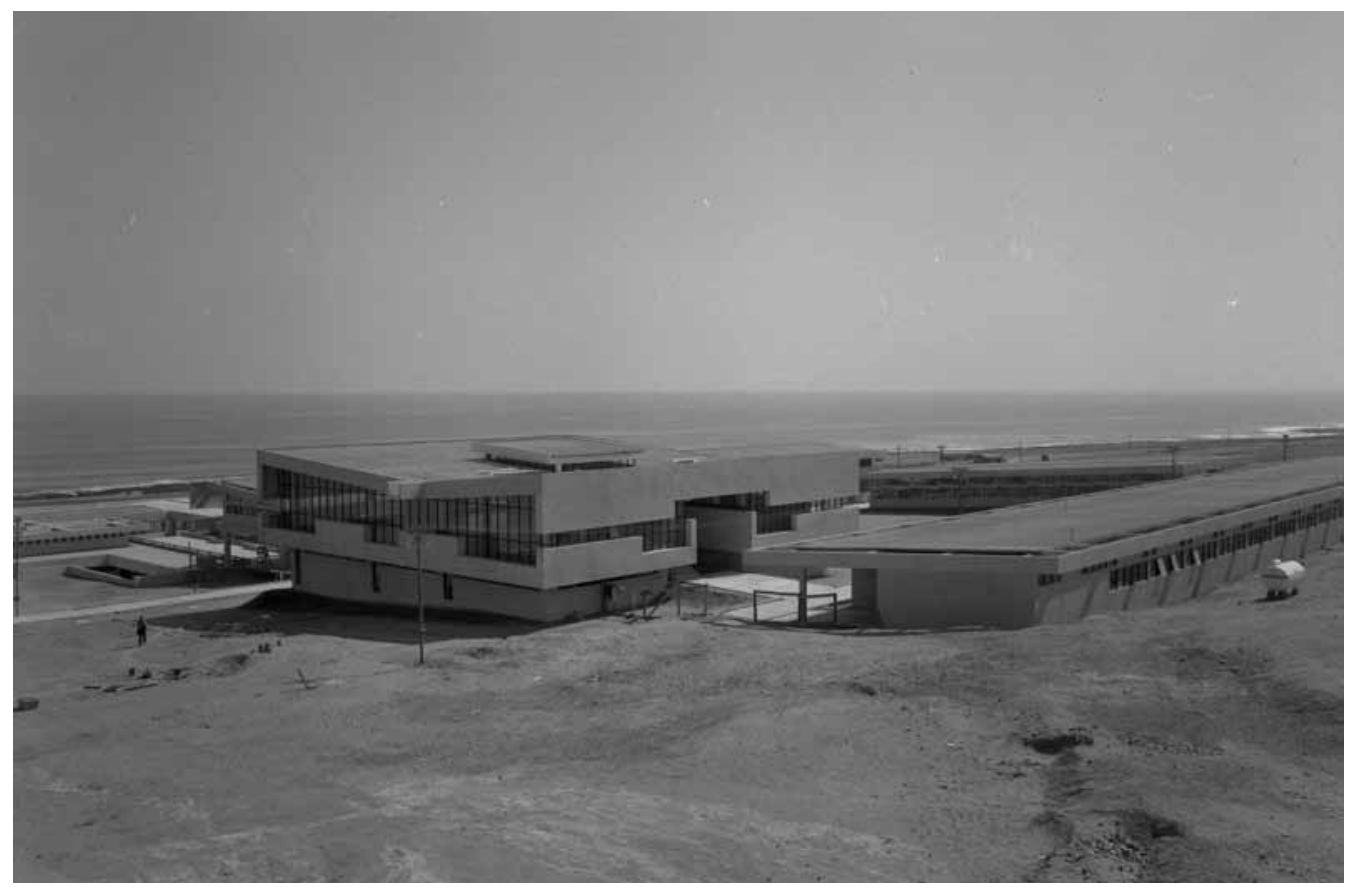




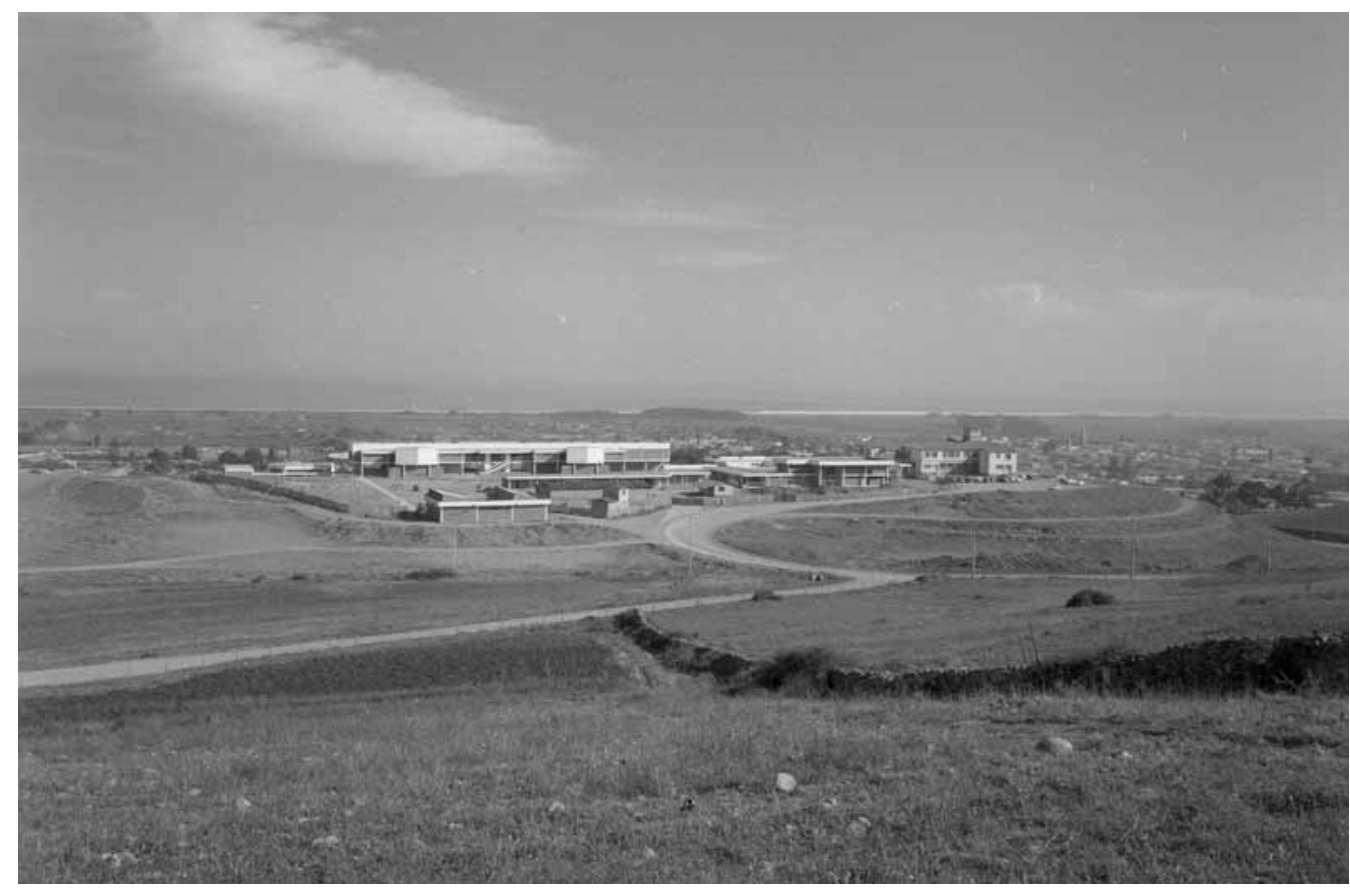

Colegio regional de La Serena Foto: Patricio Guzmán

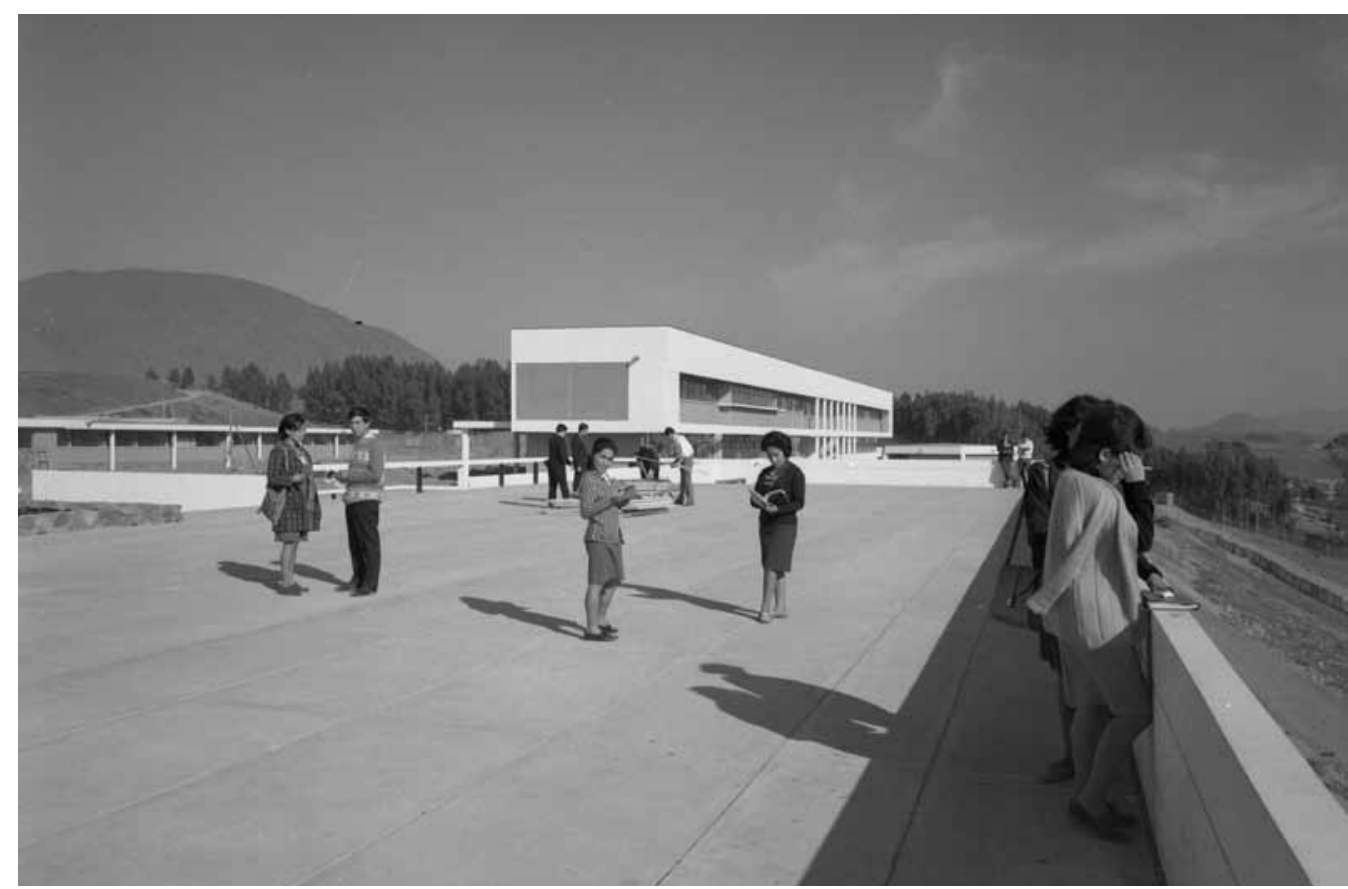
Foto: Patricio Guzmán 


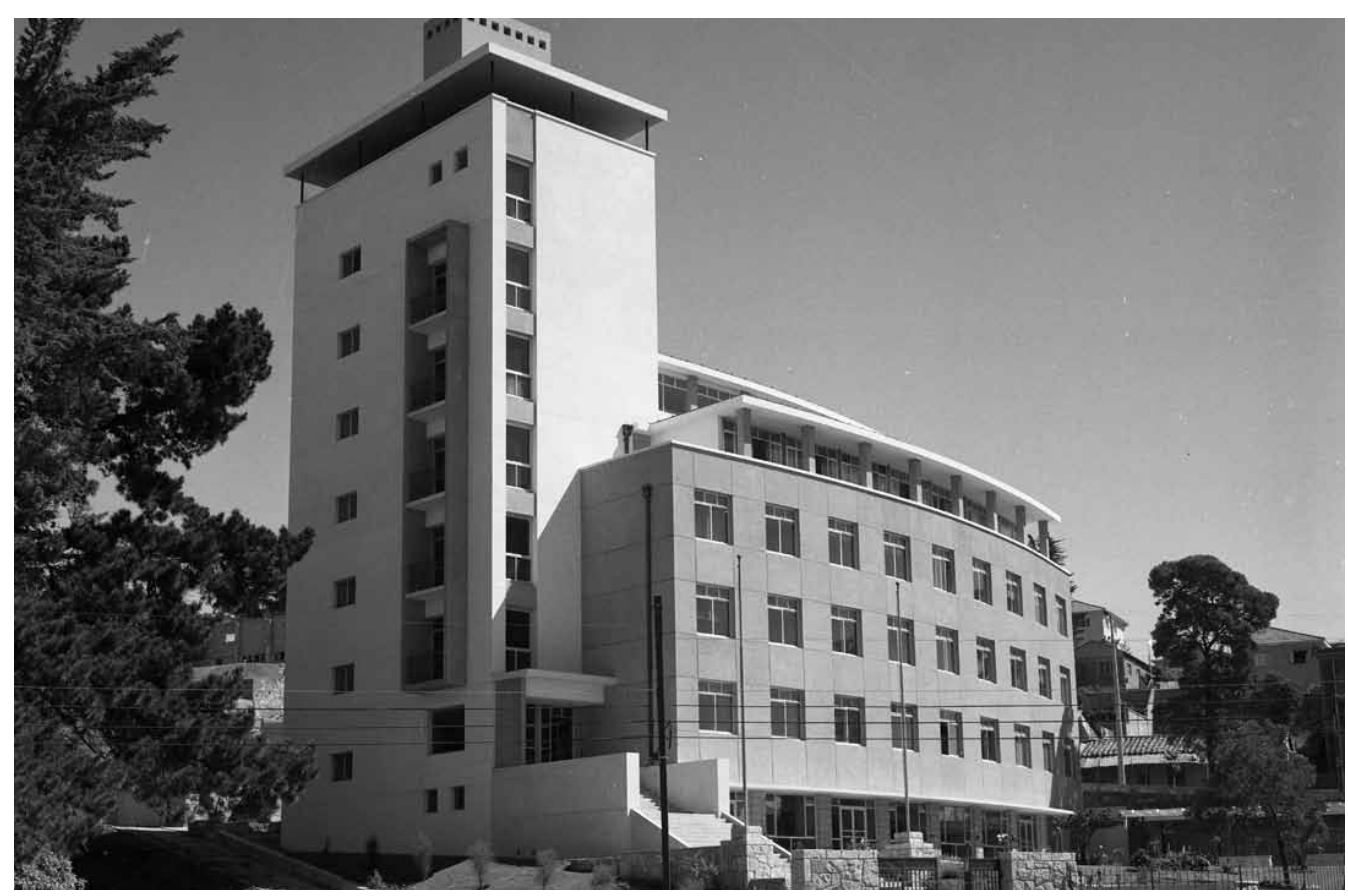

Escuela de Ciencias Biológicas de Valparaíso

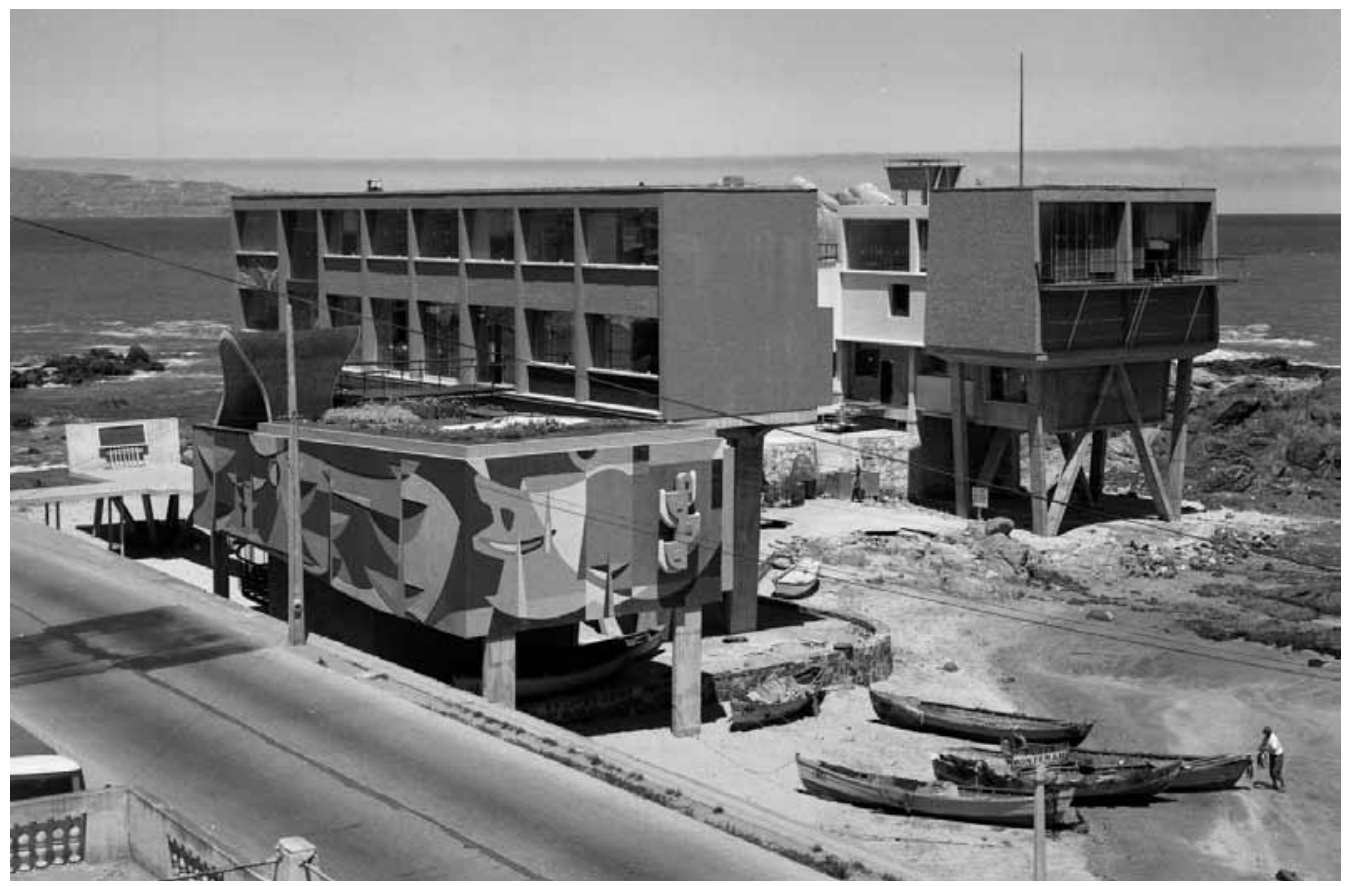




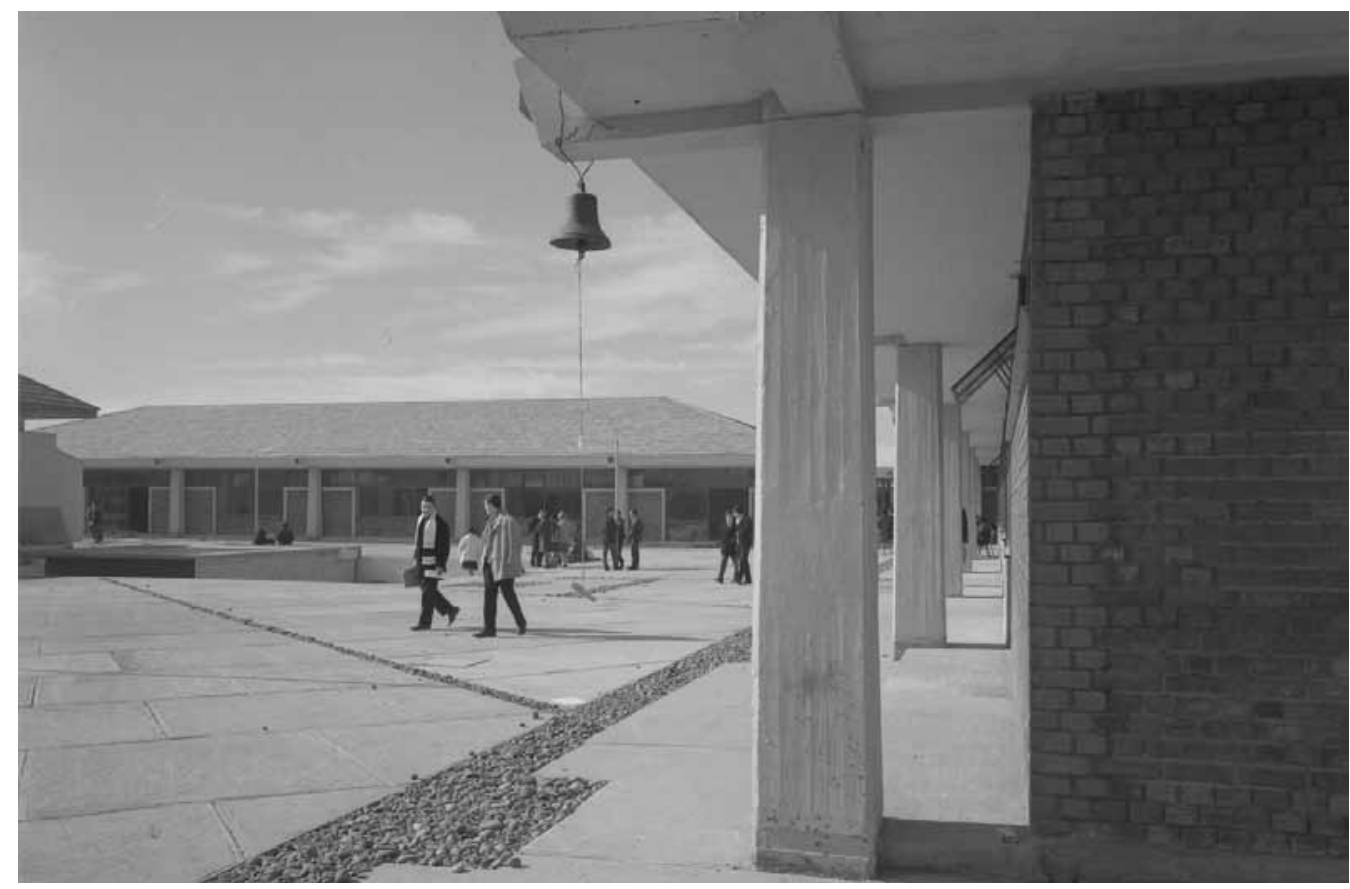

Colegio regional de Talca

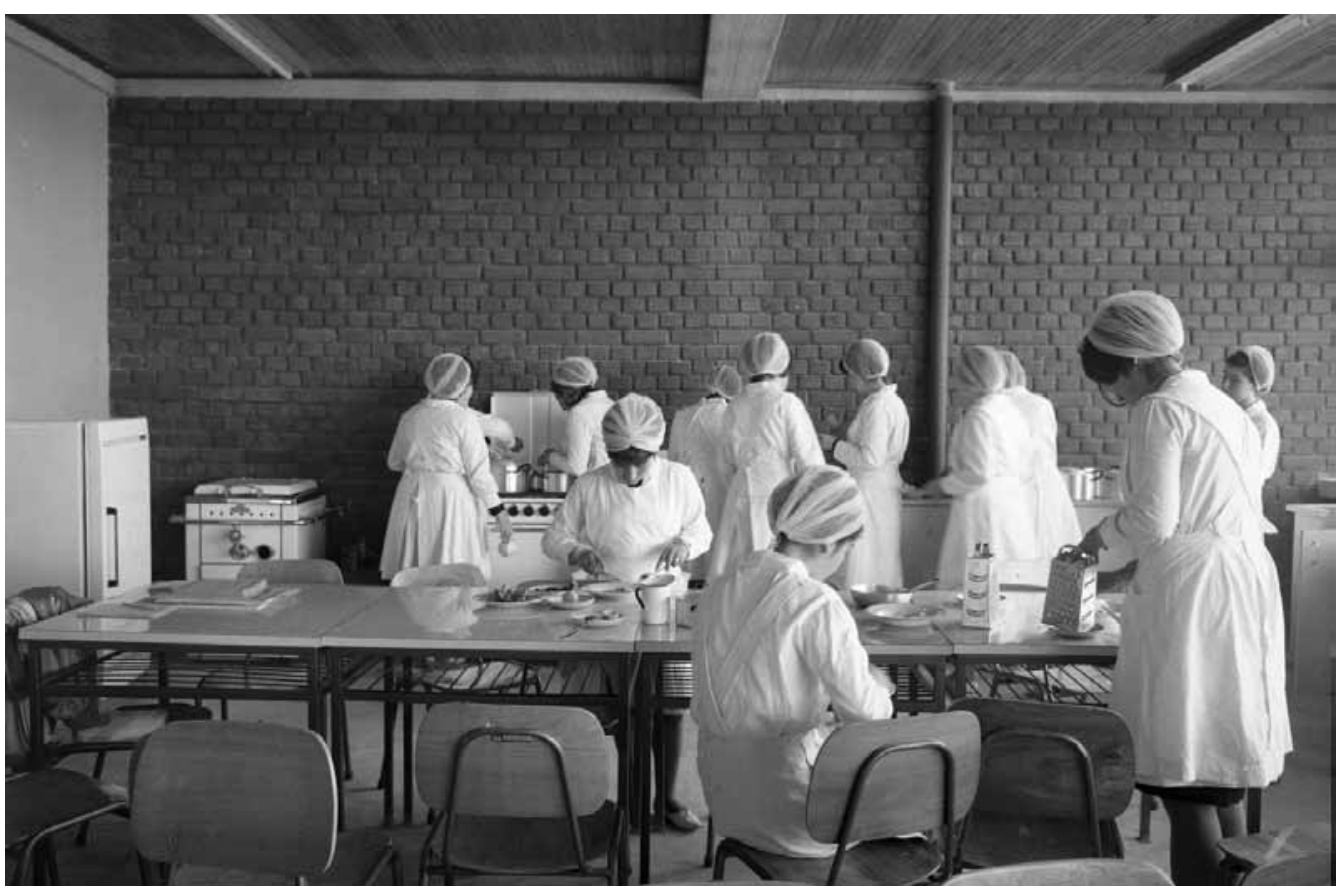

Colegio regional de Talca 


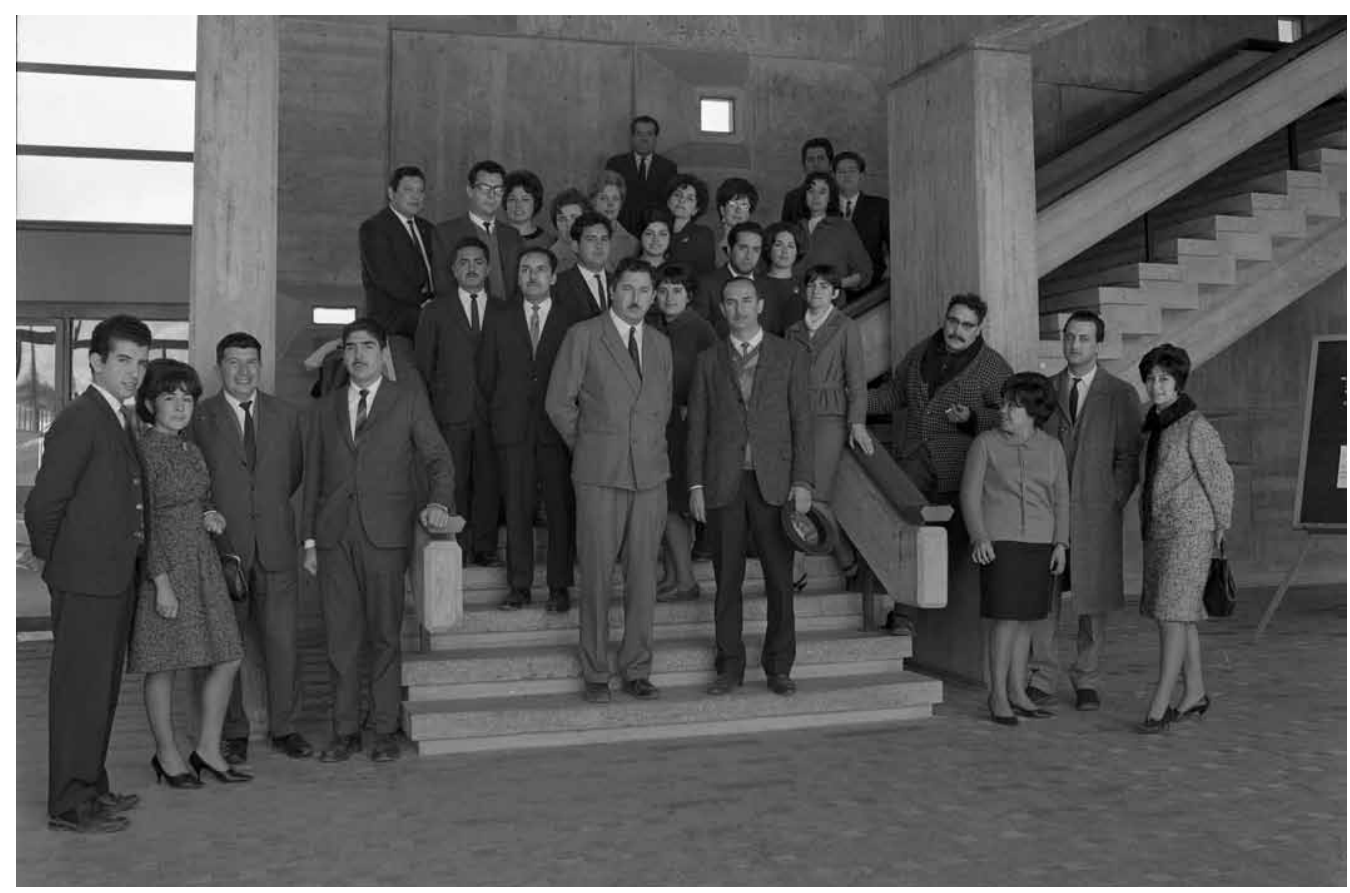

Centro regional de Osorno

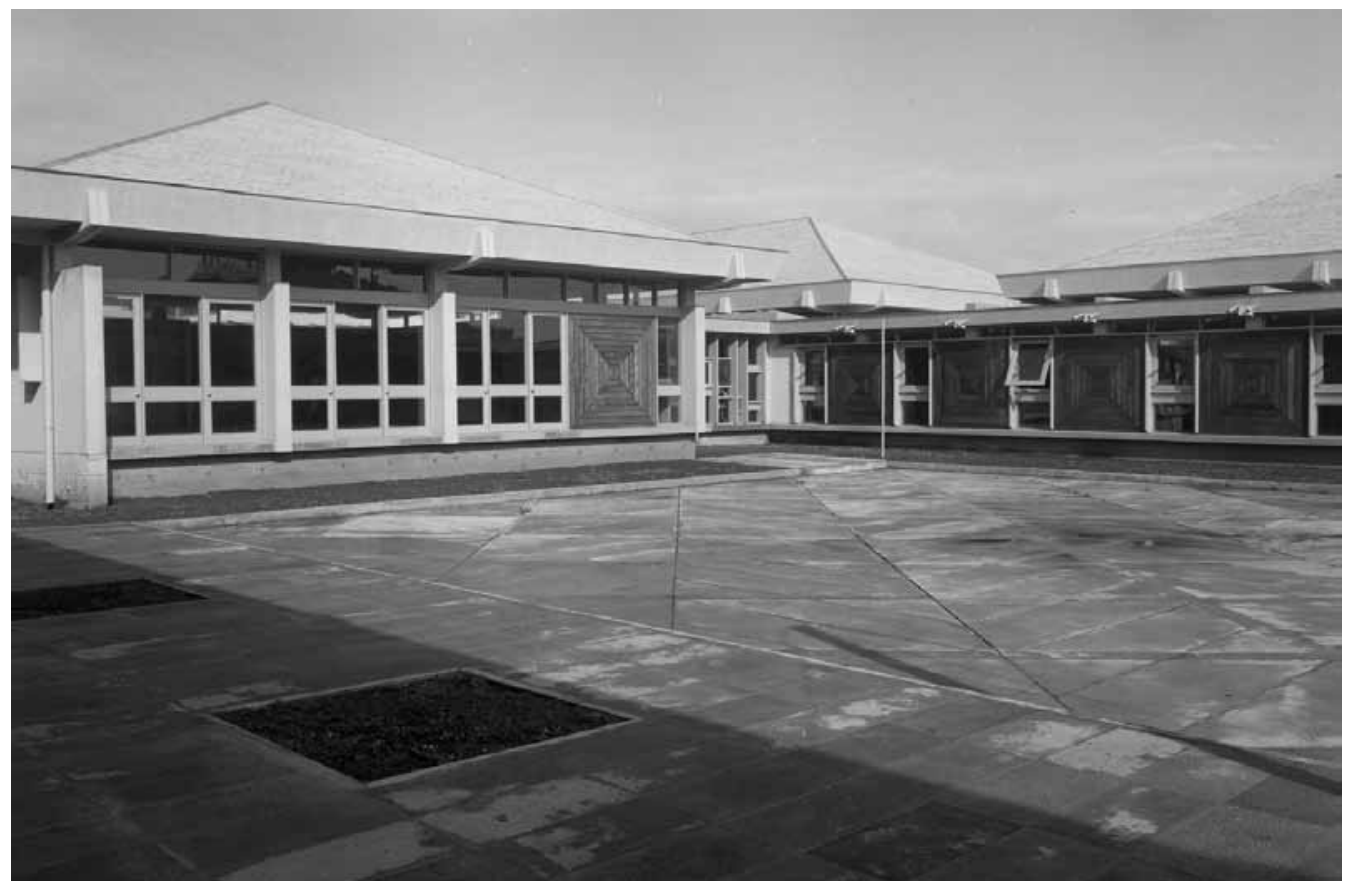




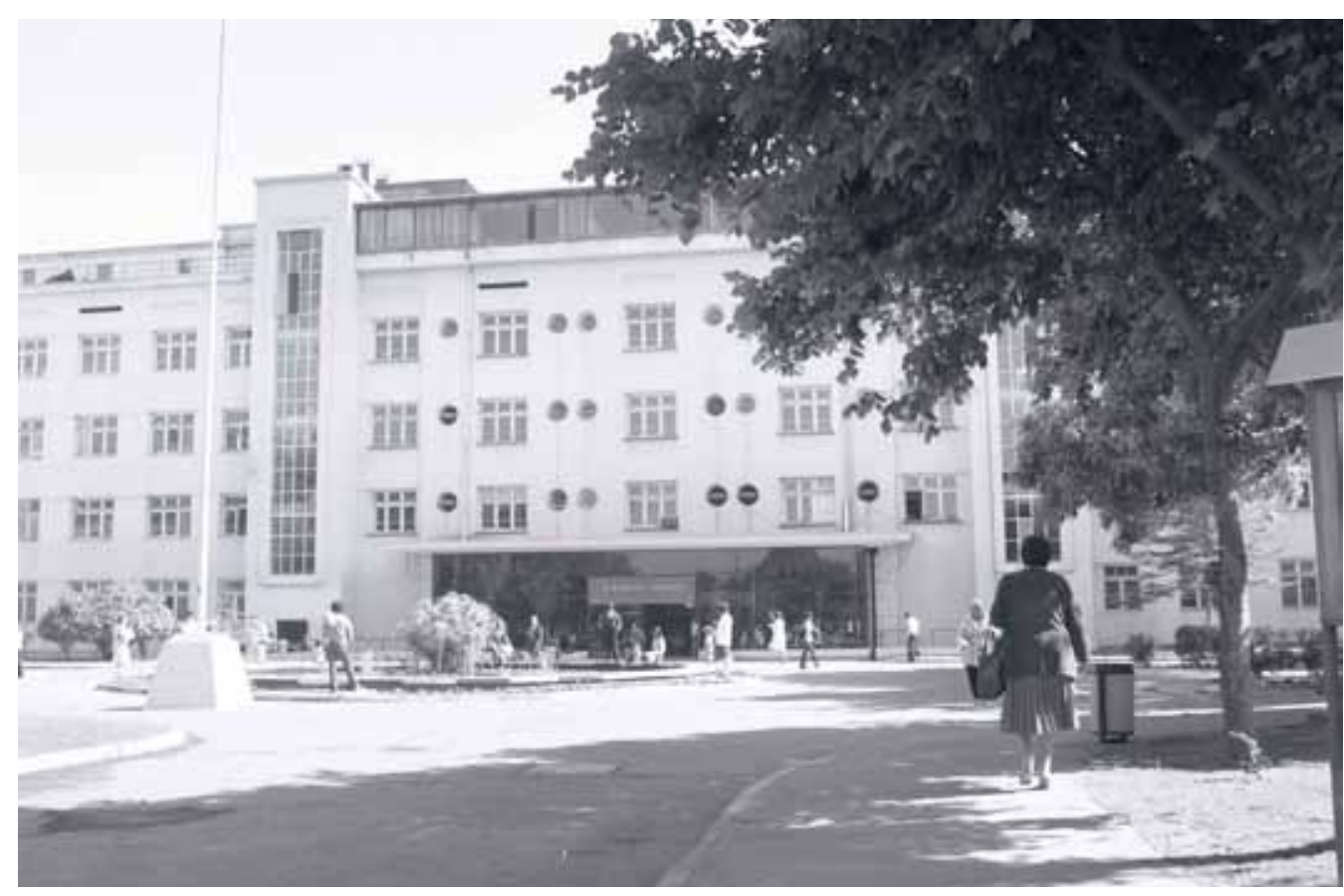

Hospital José Joaquín Aguirre

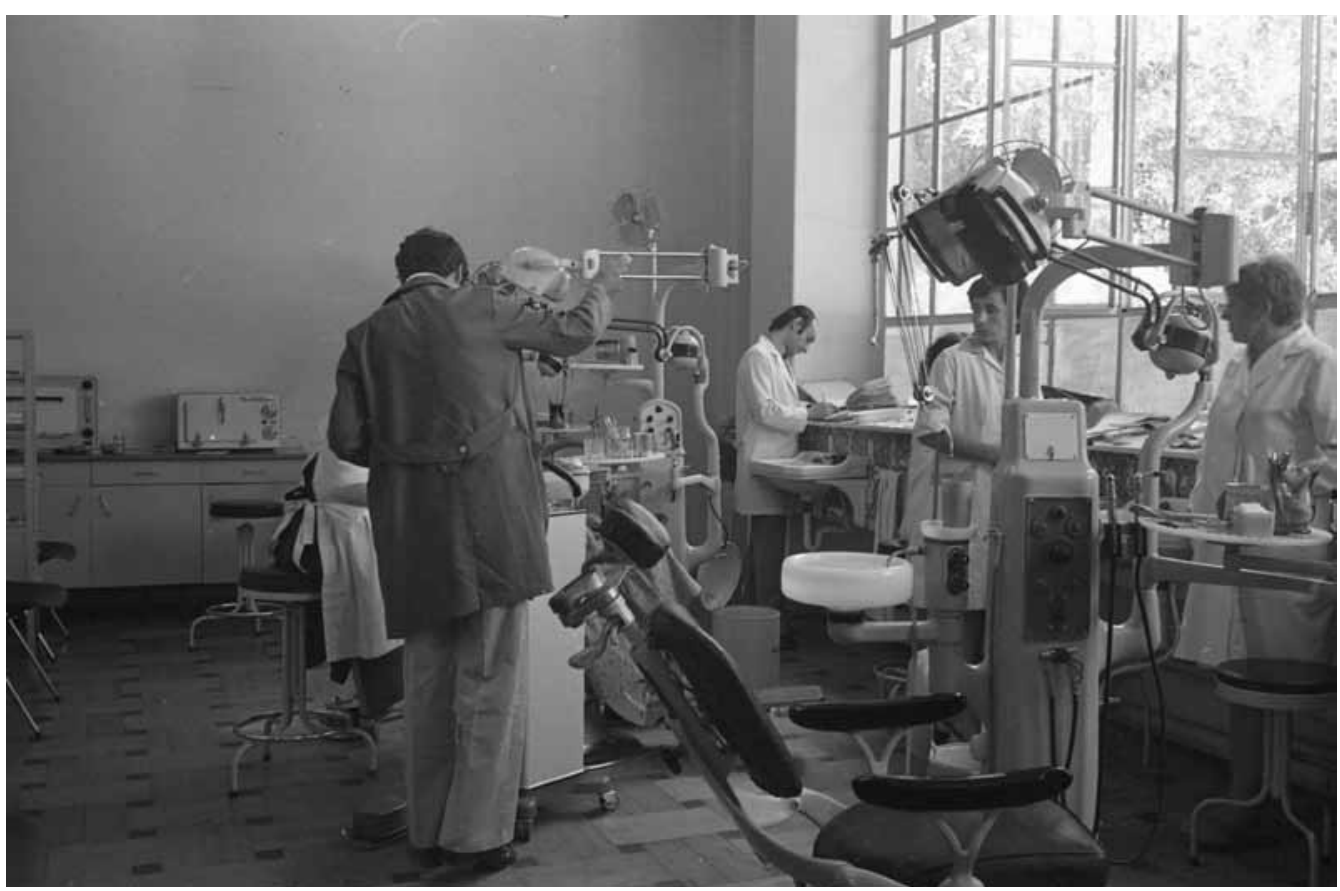

SEMDA 


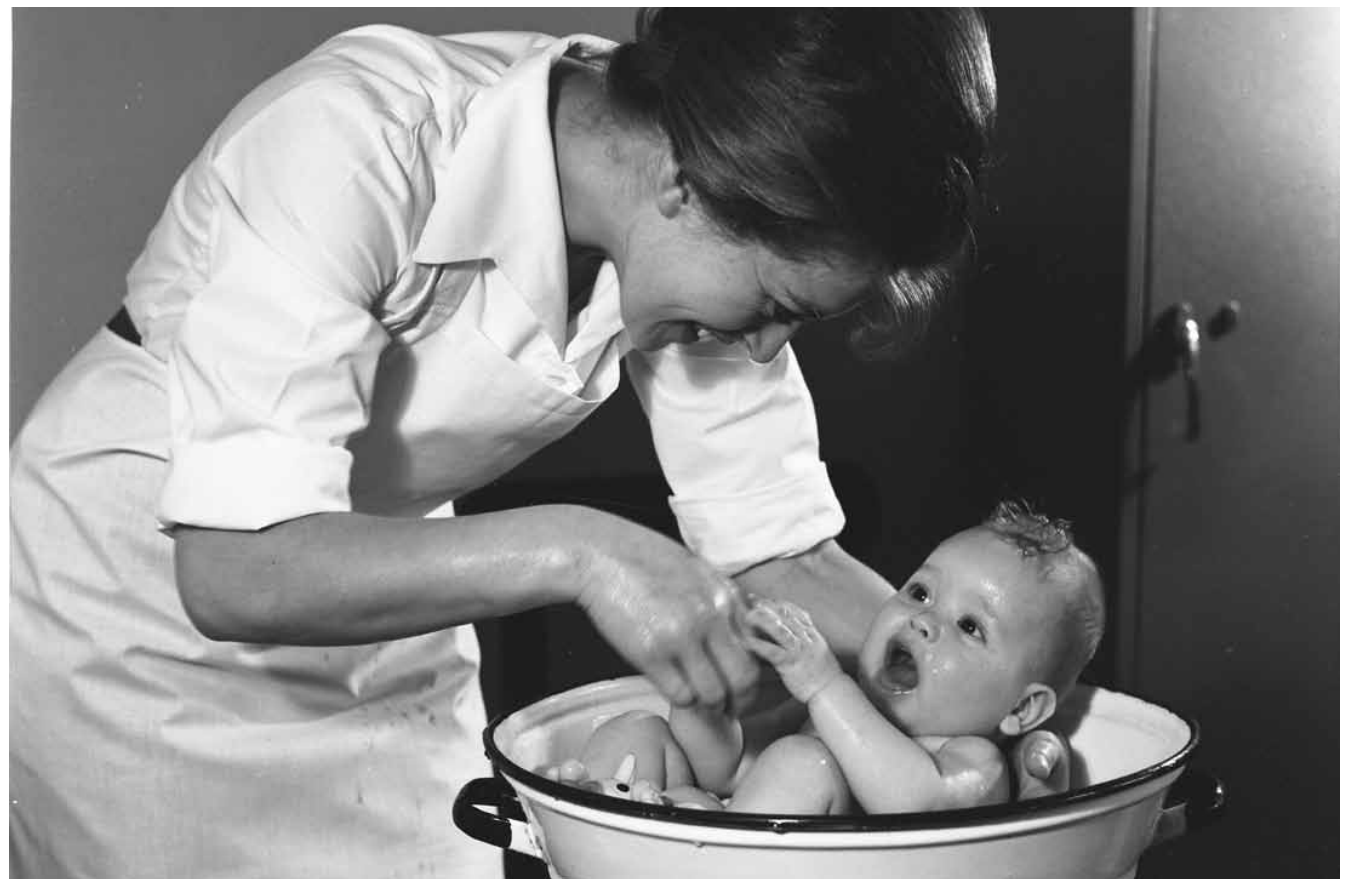

Escuela de Enfermeras

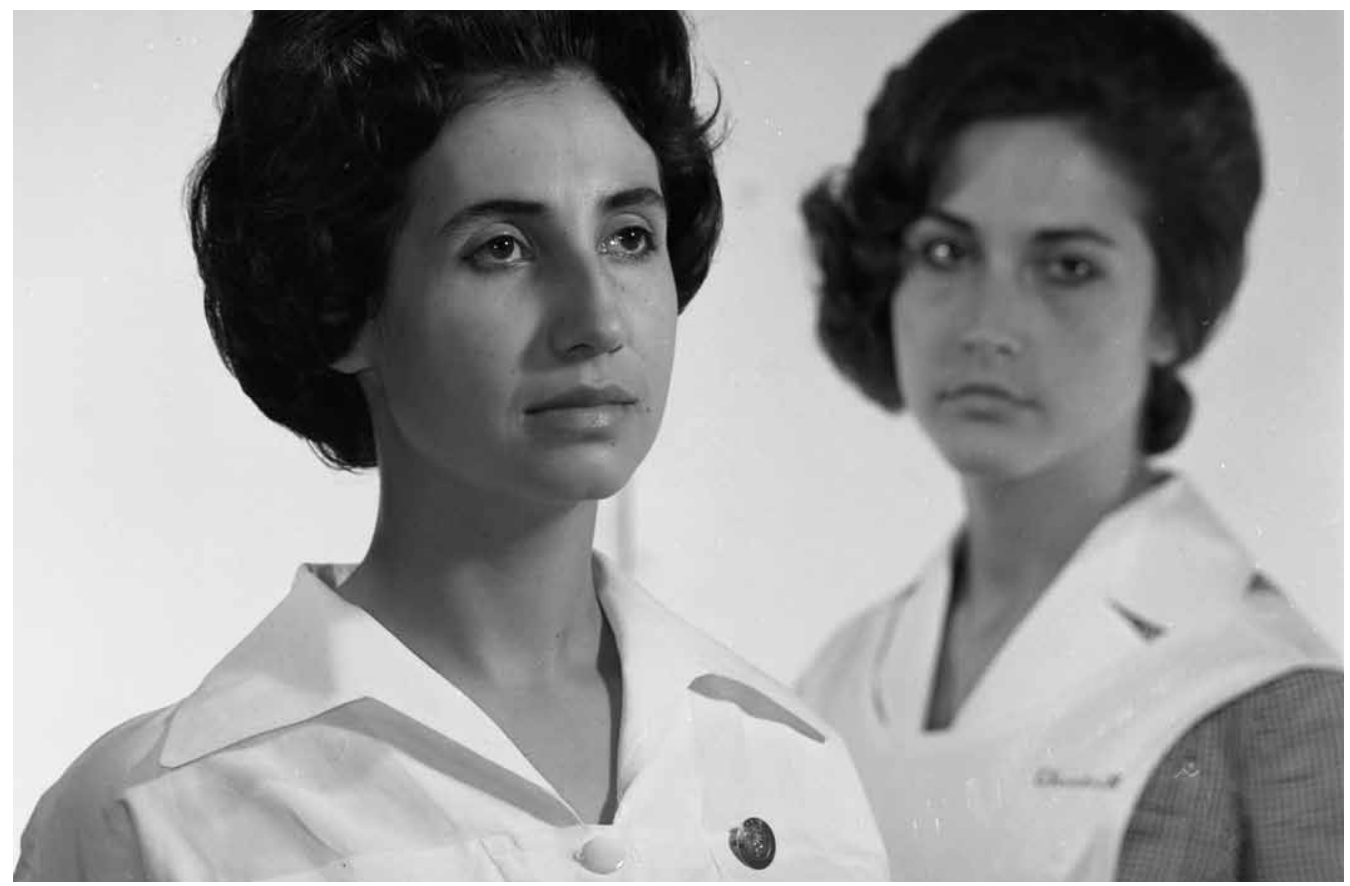

Escuela de Enfermeras 


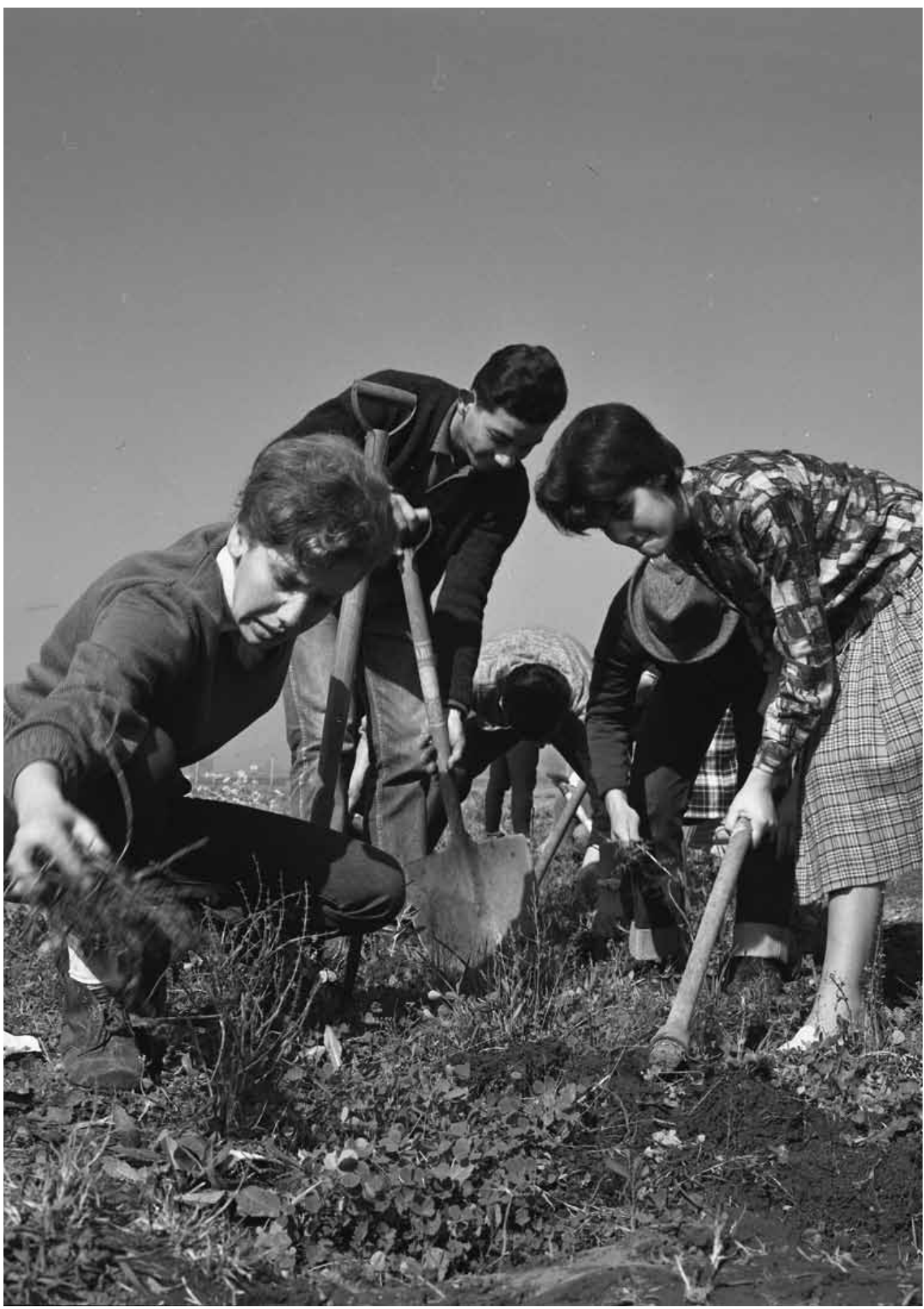




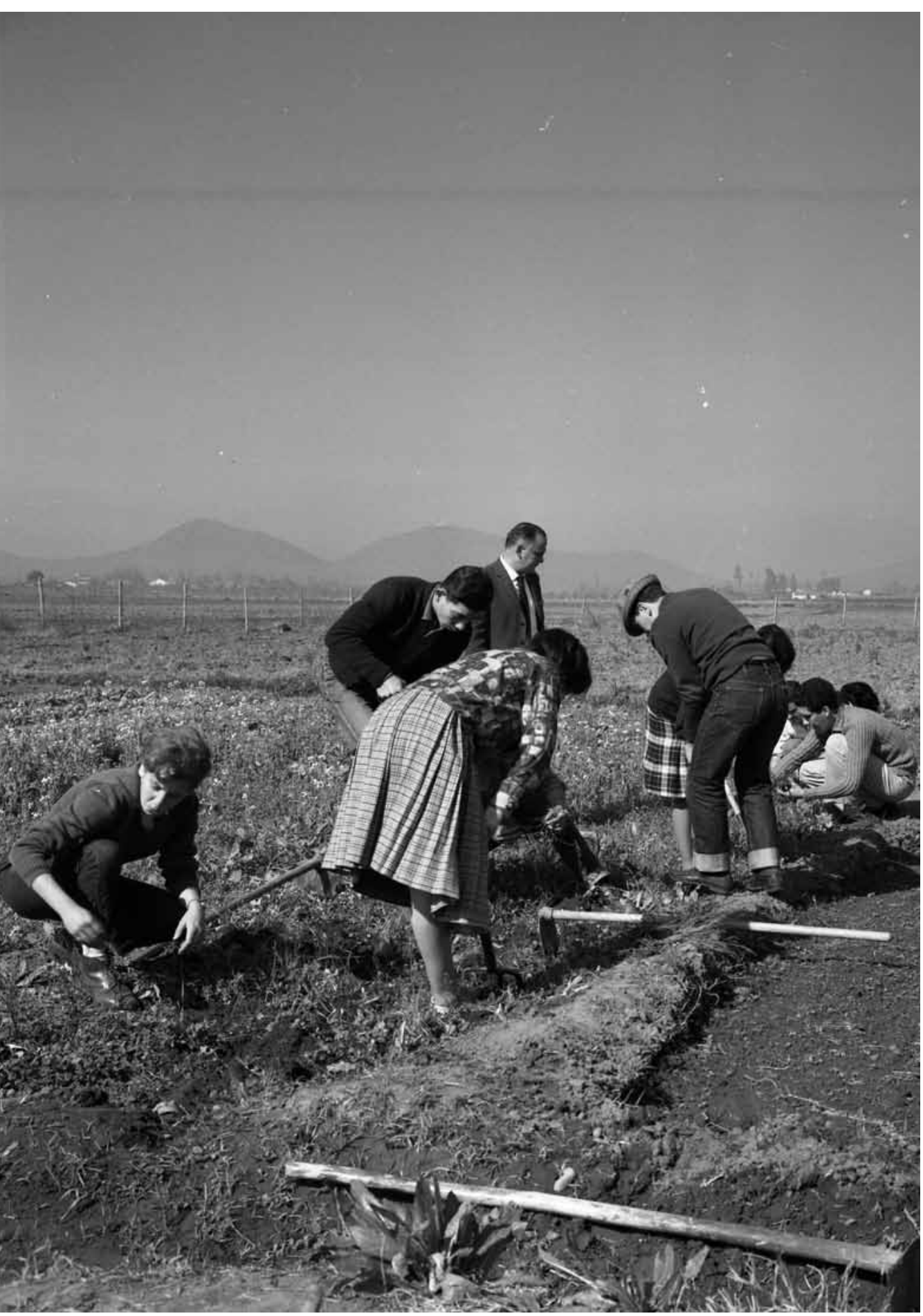



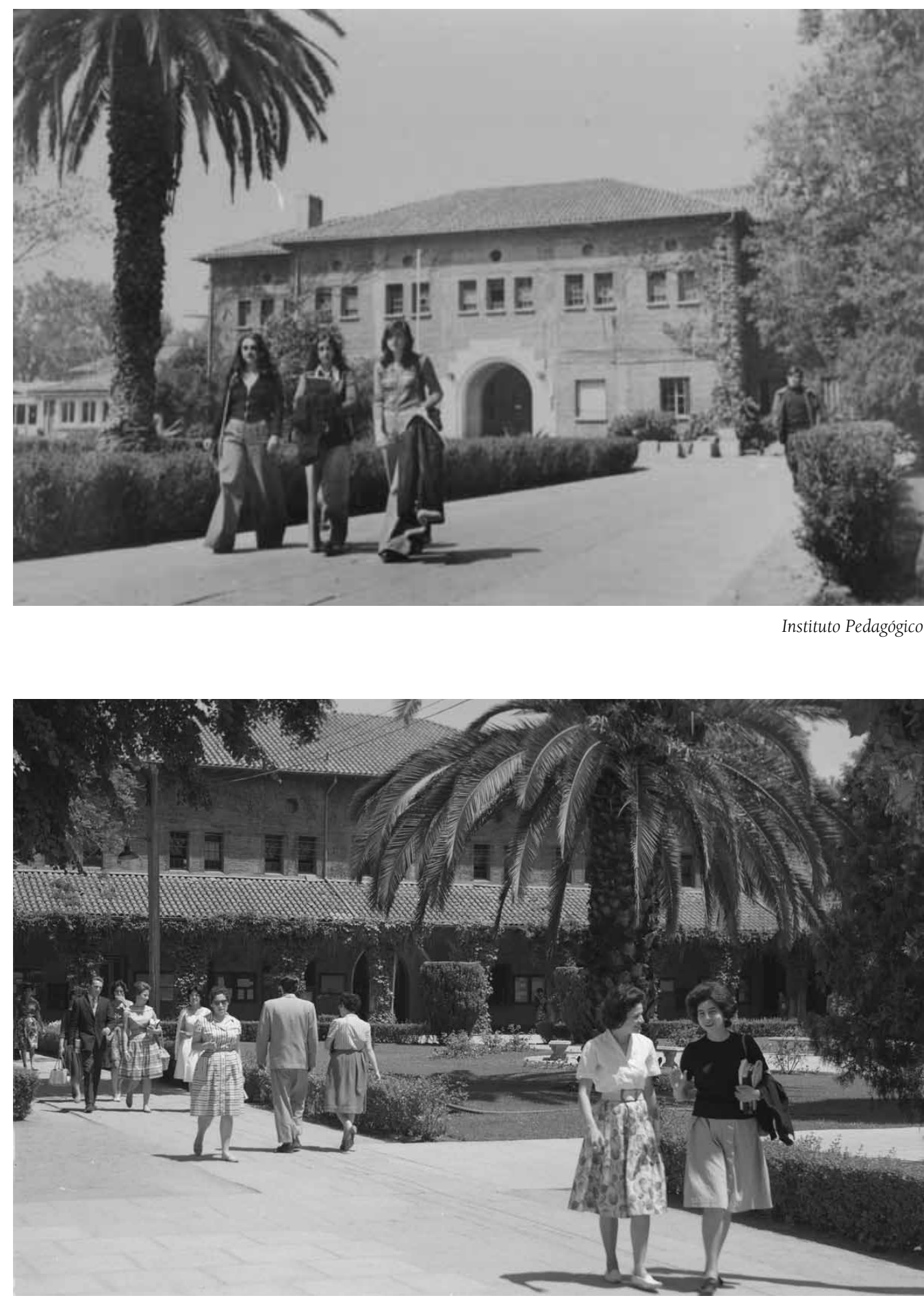


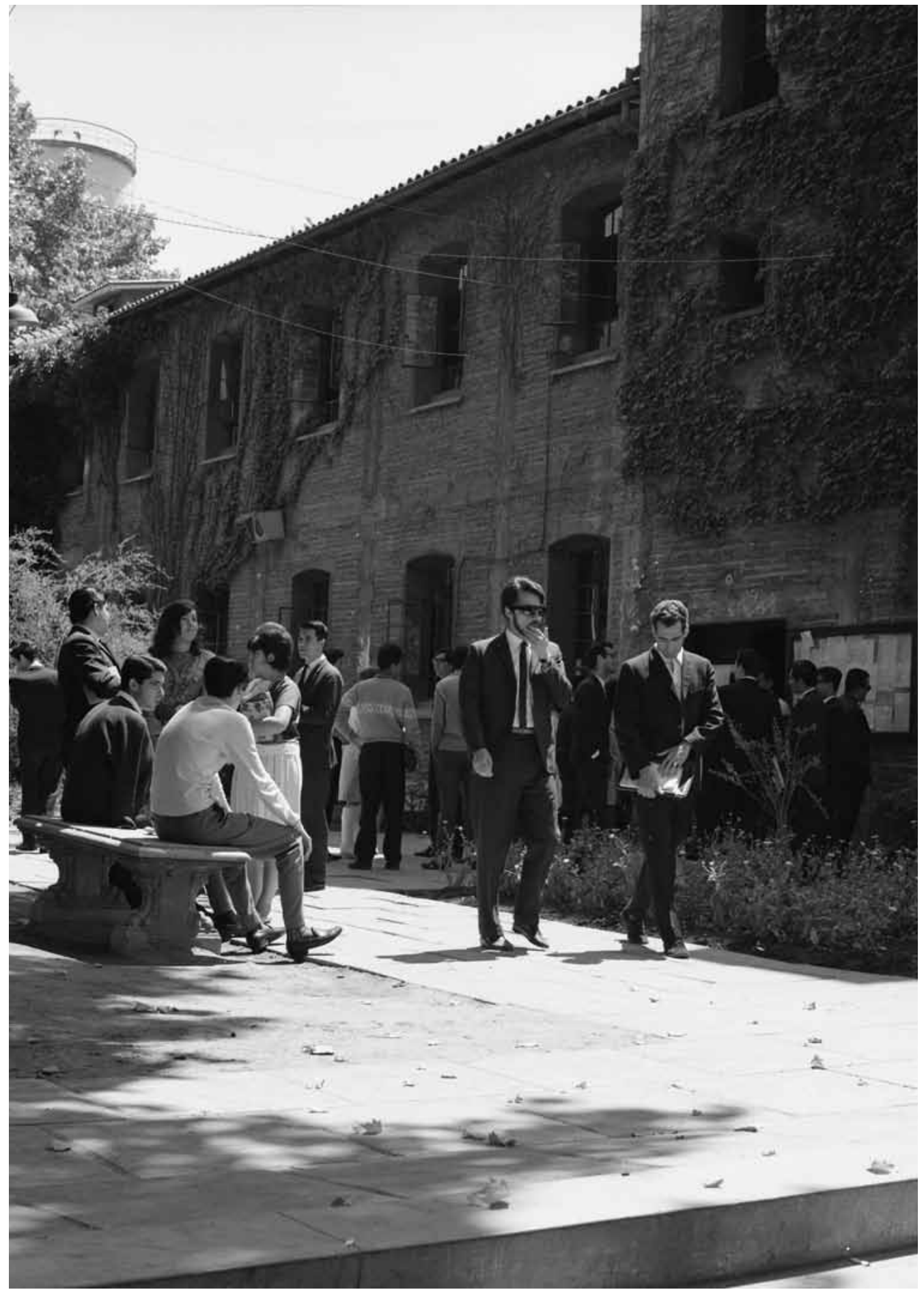




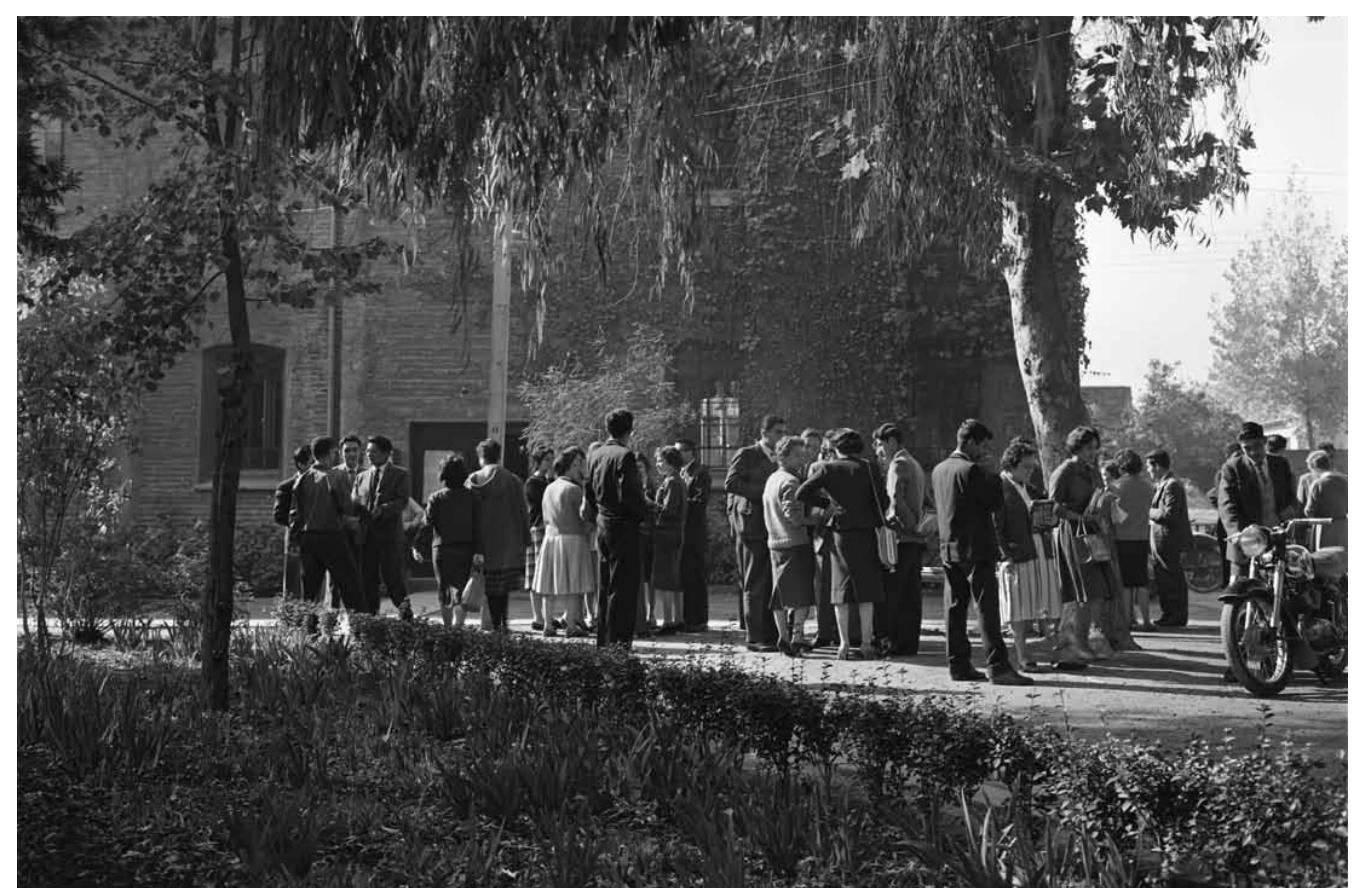

Instituto Pedagógico

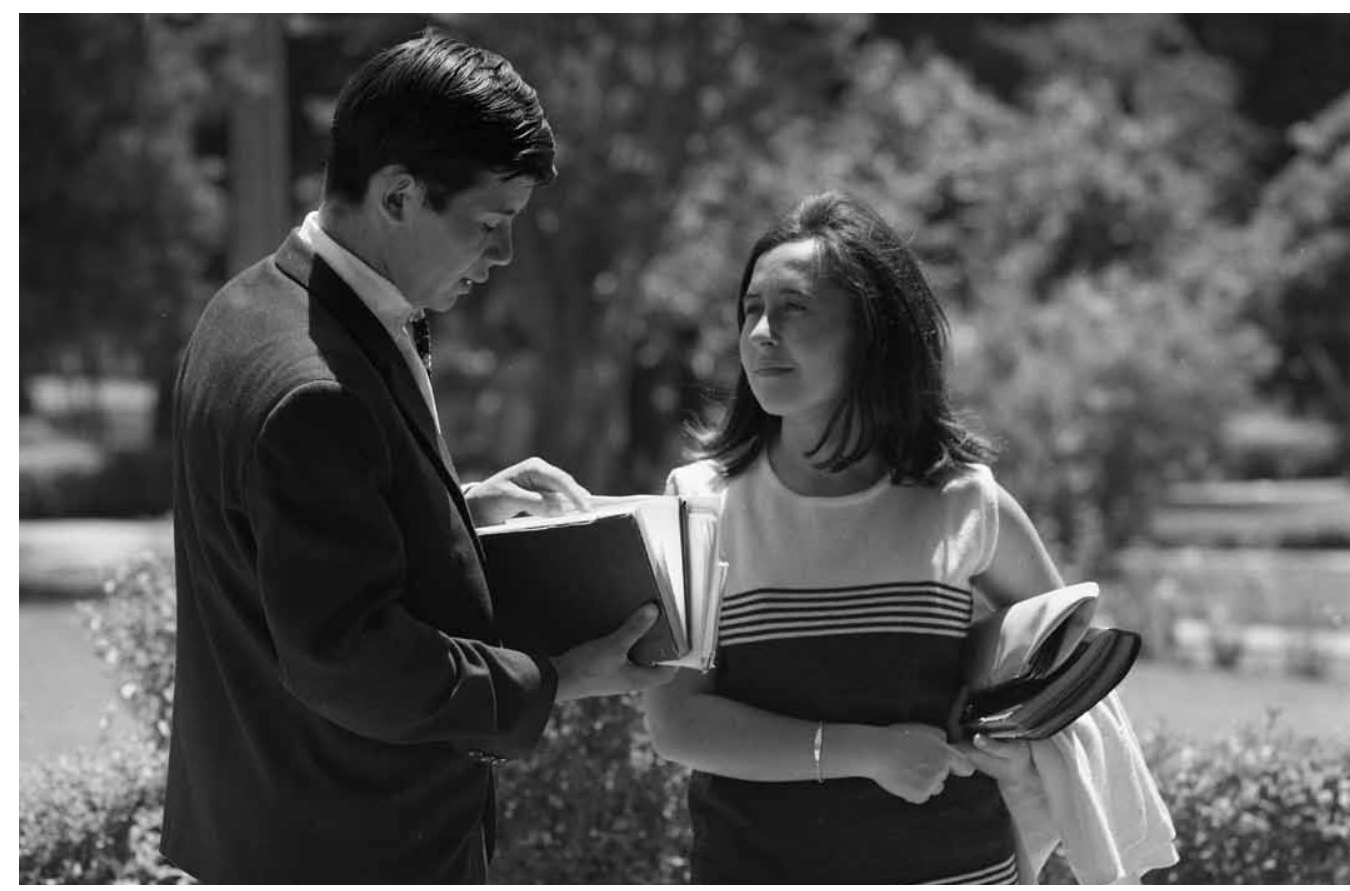




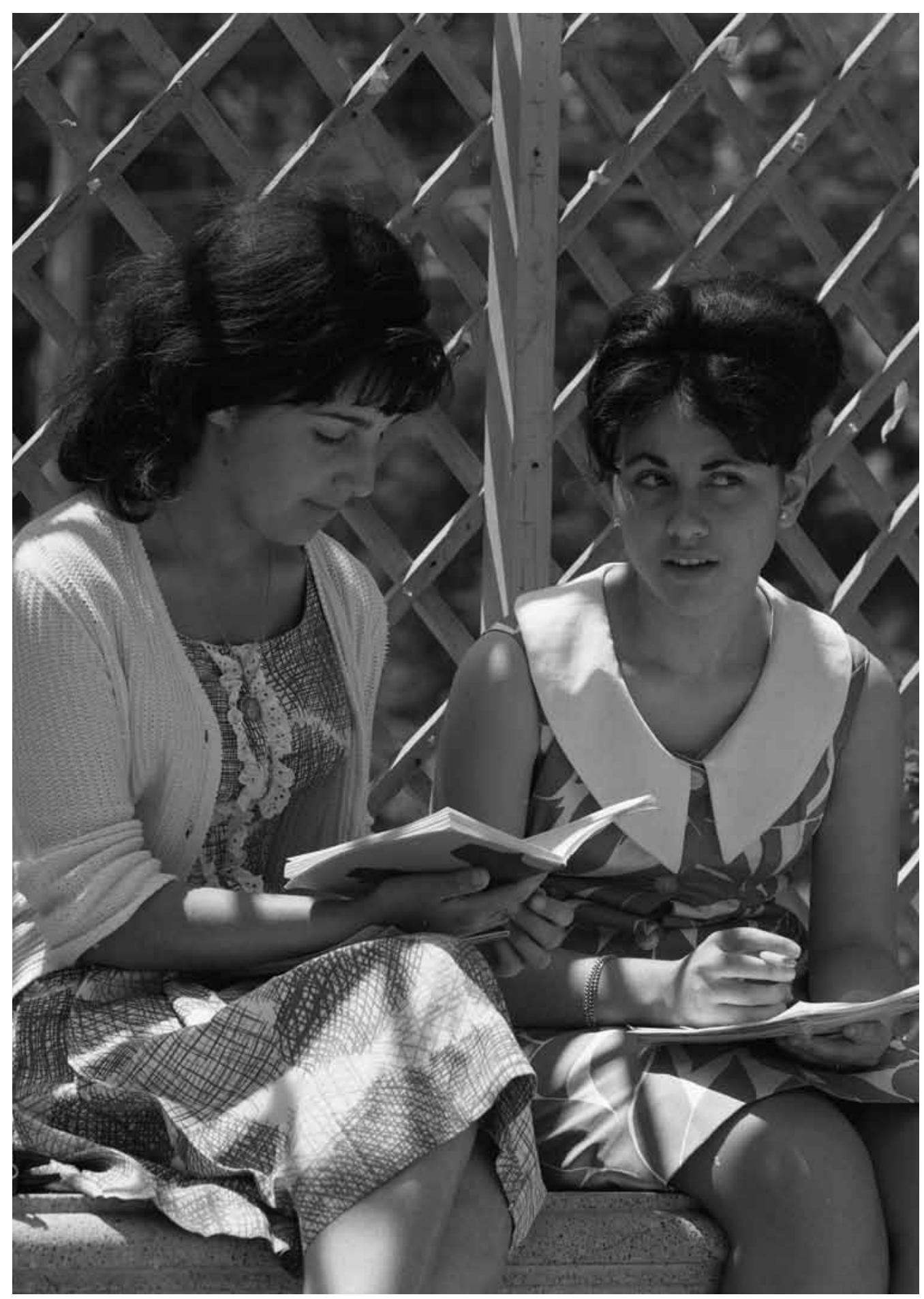




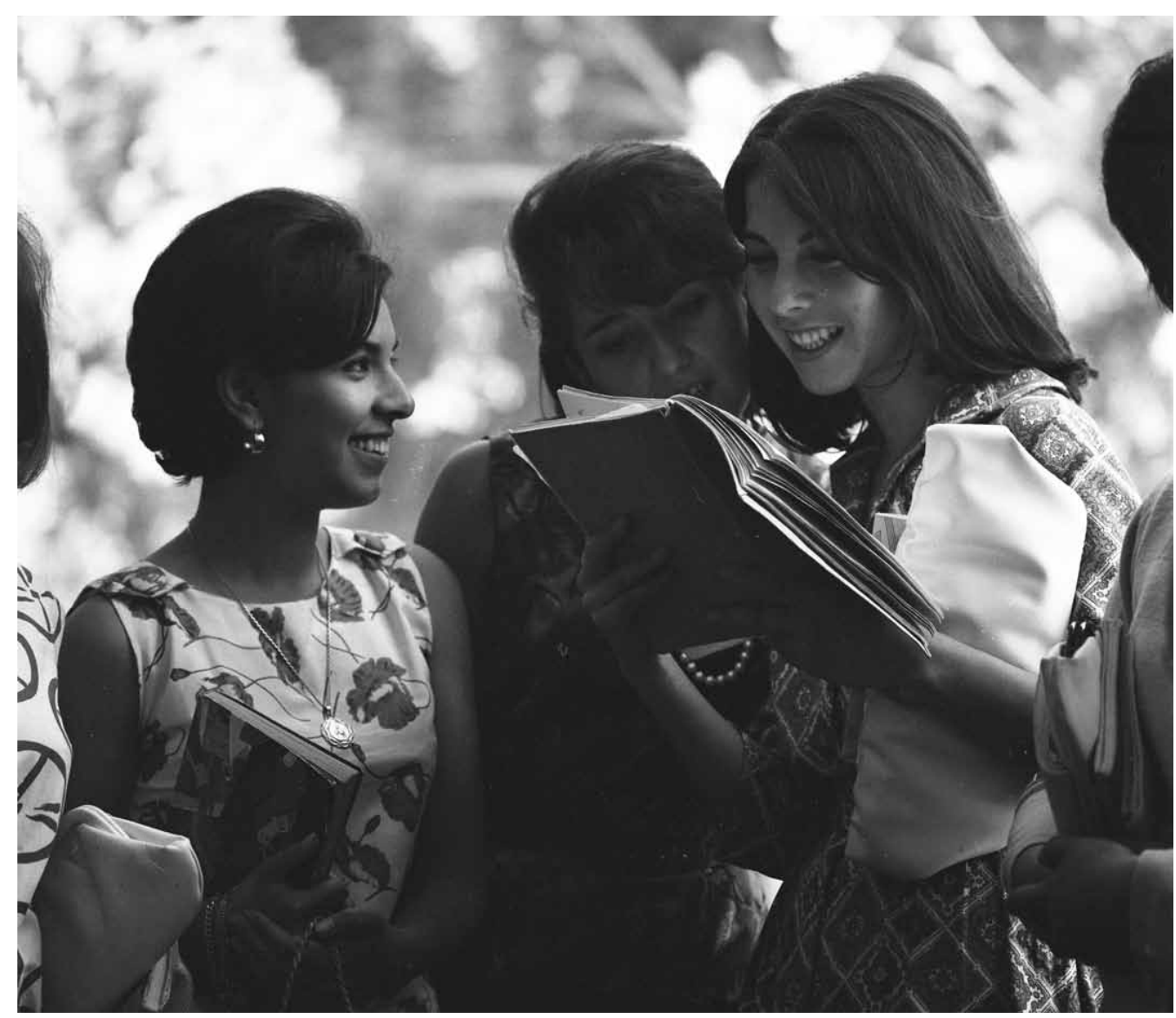

Instituto Pedagógico 


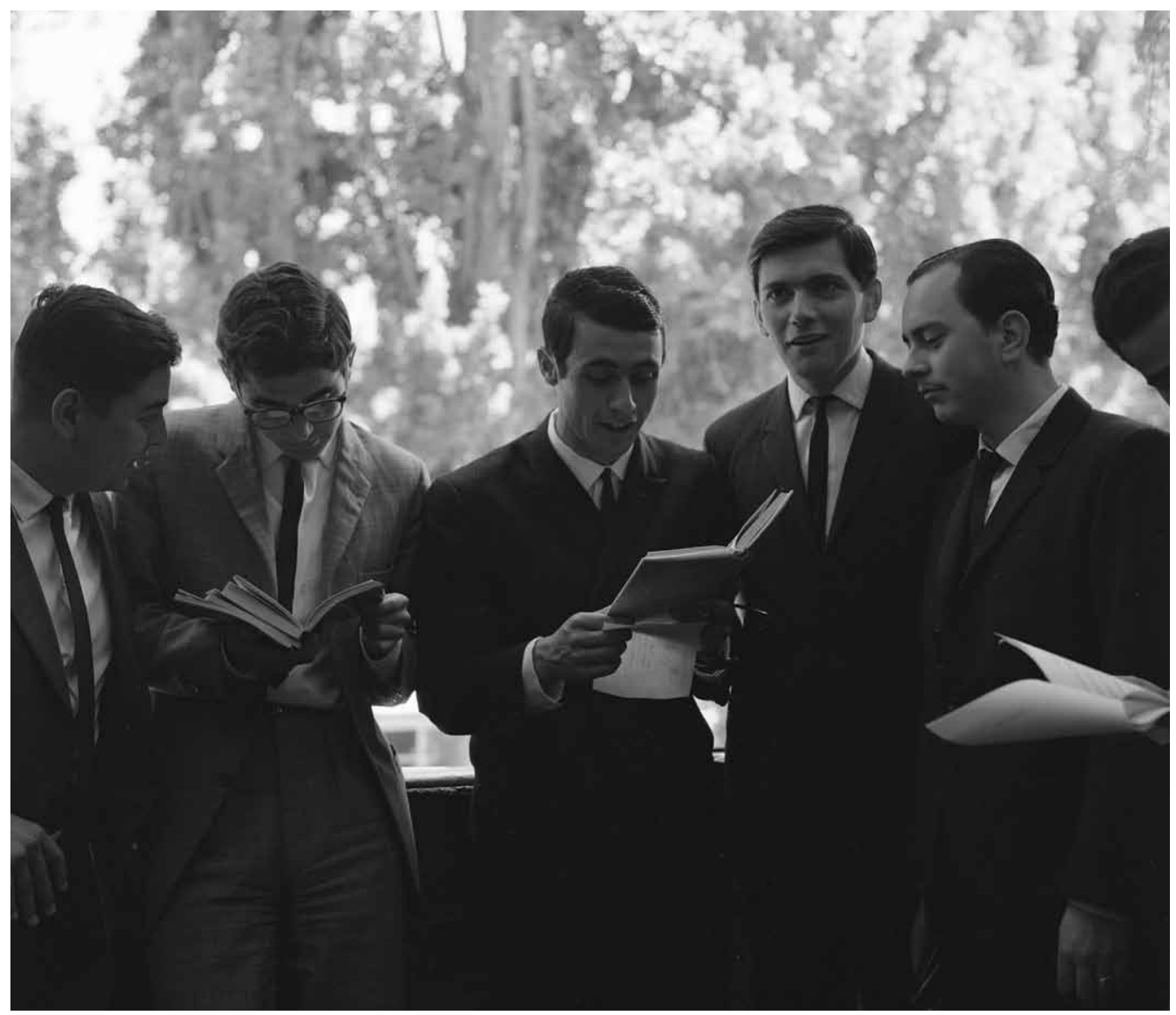

Instituto Pedagógico 


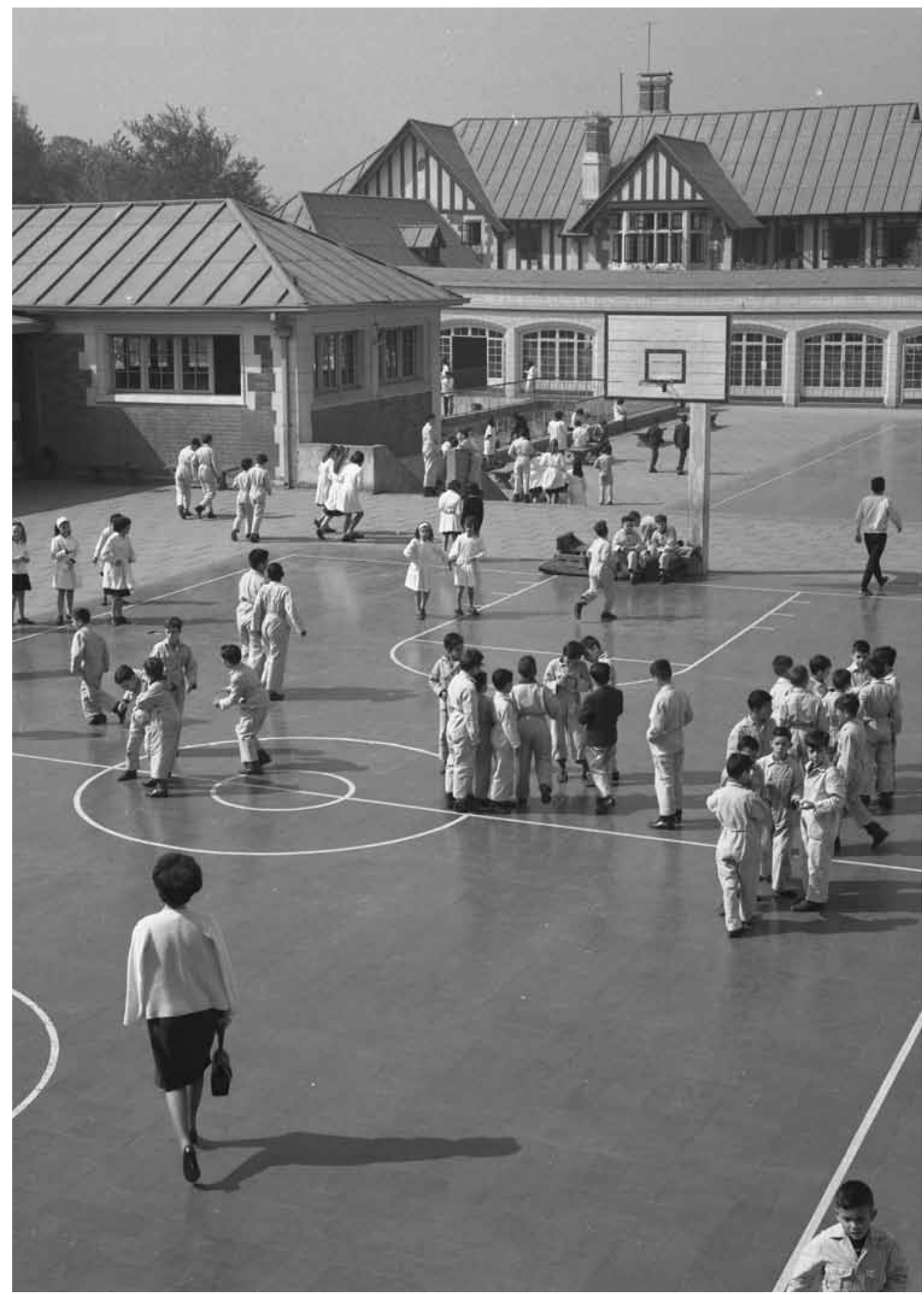




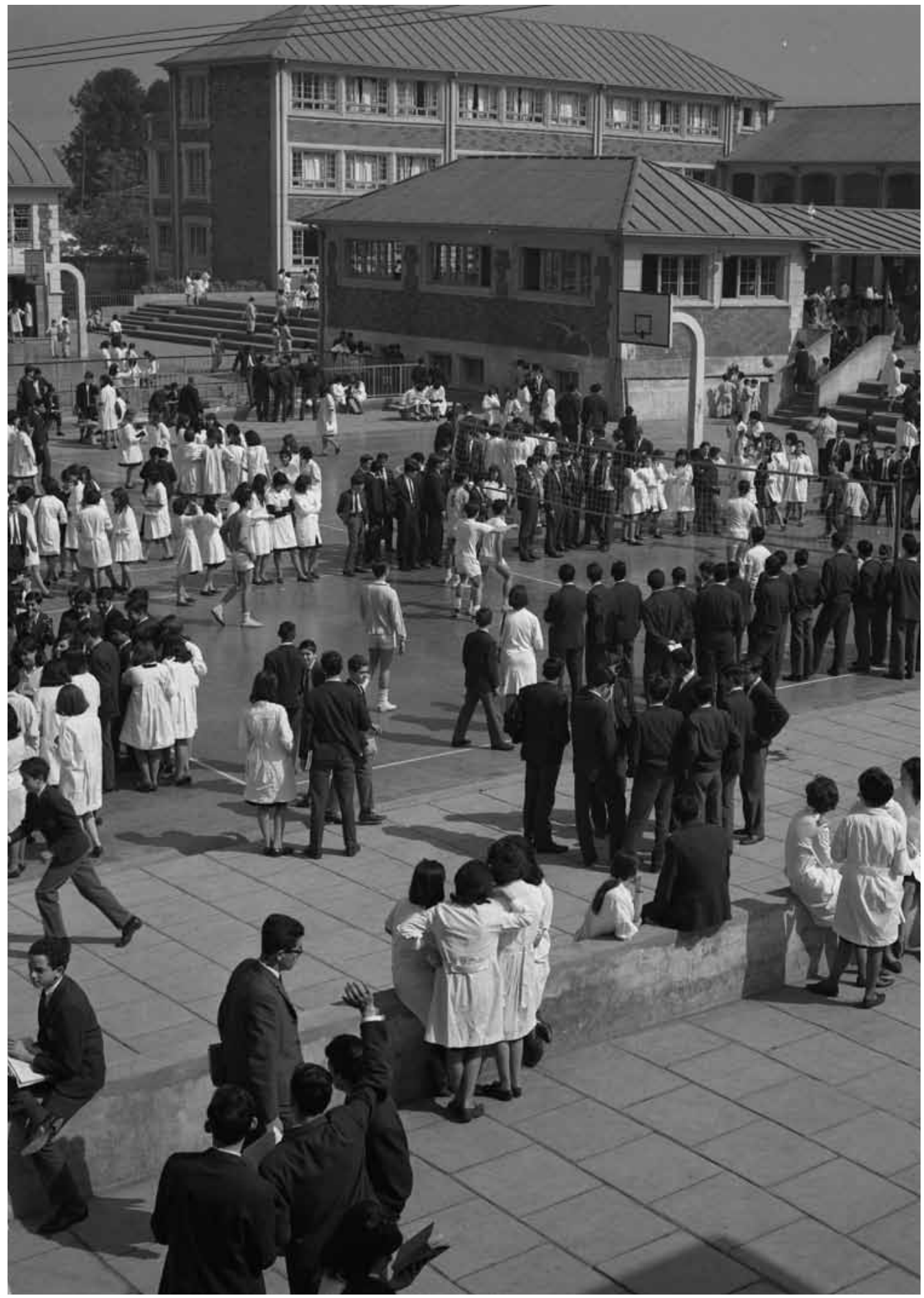




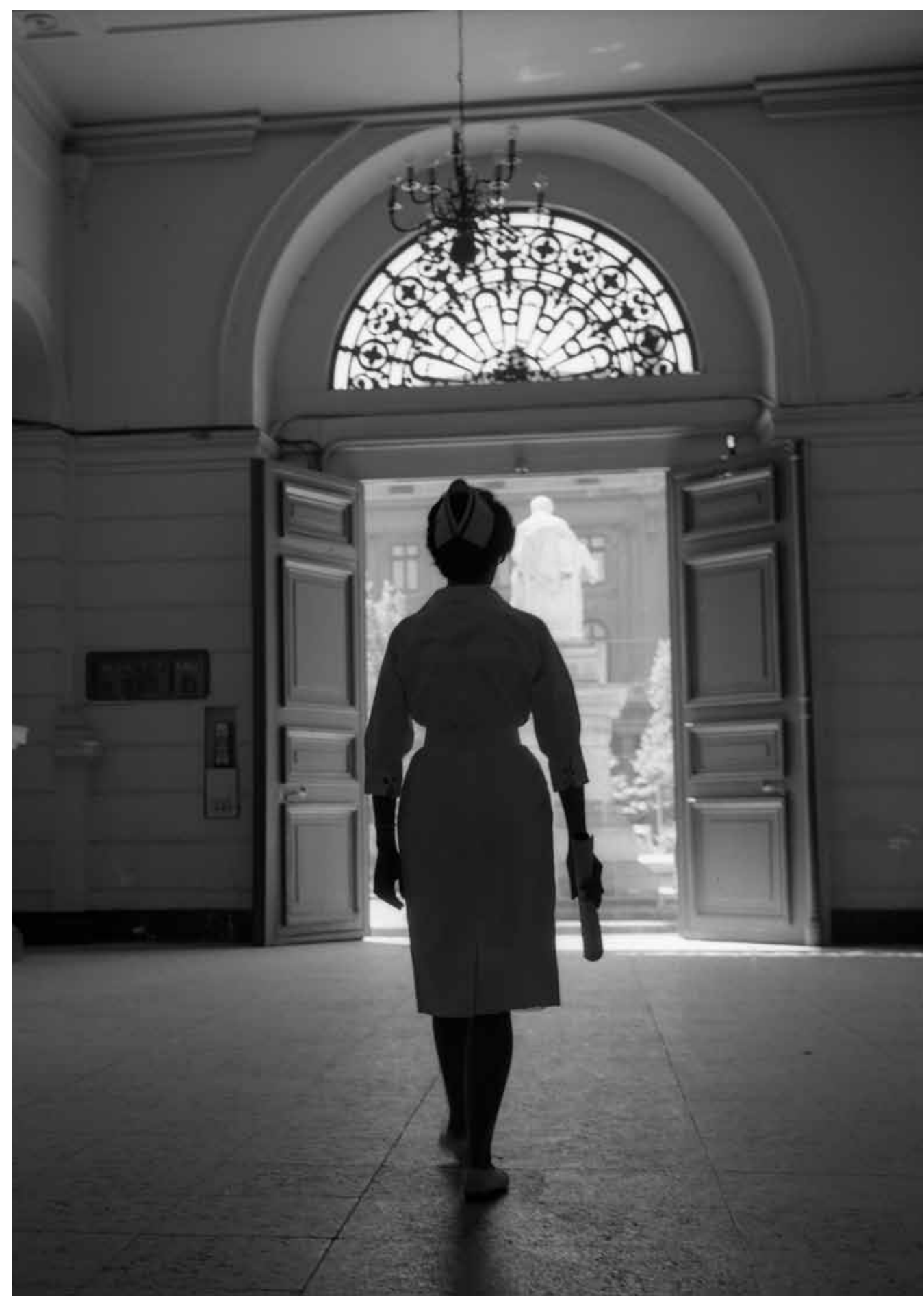

